Published in final edited form as:

Curr Gene Ther. 2005 December ; 5(6): 535-557.

\title{
Gene Therapy and Targeted Toxins for Glioma
}

\author{
Gwendalyn D. King ${ }^{1,2}$, James F. Curtin ${ }^{1,2}$, Marianela Candolfi ${ }^{1}$, Kurt Kroeger ${ }^{1}$, Pedro R. \\ Lowenstein ${ }^{1}$, and Maria G. Castro ${ }^{1,{ }^{*}}$ \\ 1 Gene Therapeutics Research Institute, Cedars-Sinai Medical Center and Department of Molecular \\ and Medical Pharmacology, UCLA, Research Pavilion, Suite 5090, 8700 Beverly Boulevard, Los \\ Angeles, CA 90048, USA \\ 2Department of Medicine, David Geffen School of Medicine, UCLA, Research Pavilion, Suite 5090, \\ 8700 Beverly Boulevard, Los Angeles, CA 90048, USA
}

\section{Abstract}

The most common primary brain tumor in adults is glioblastoma. These tumors are highly invasive and aggressive with a mean survival time of nine to twelve months from diagnosis to death. Current treatment modalities are unable to significantly prolong survival in patients diagnosed with glioblastoma. As such, glioma is an attractive target for developing novel therapeutic approaches utilizing gene therapy. This review will examine the available preclinical models for glioma including xenographs, syngeneic and genetic models. Several promising therapeutic targets are currently being pursued in pre-clinical investigations. These targets will be reviewed by mechanism of action, i.e., conditional cytotoxic, targeted toxins, oncolytic viruses, tumor suppressors/oncogenes, and immune stimulatory approaches. Preclinical gene therapy paradigms aim to determine which strategies will provide rapid tumor regression and long-term protection from recurrence. While a wide range of potential targets are being investigated preclinically, only the most efficacious are further transitioned into clinical trial paradigms. Clinical trials reported to date are summarized including results from conditionally cytotoxic, targeted toxins, oncolytic viruses and oncogene targeting approaches. Clinical trial results have not been as robust as preclinical models predicted, this could be due to the limitations of the GBM models employed. Once this is addressed, and we develop effective gene therapies in models that better replicate the clinical scenario, gene therapy will provide a powerful approach to treat and manage brain tumors.

\section{Keywords}

Glioma; gene therapy; dendritic cells; CD4T cells; CD8T cells; immunotherapy; cytokines; Flt3L; HSV1-TK

\section{A. INTRODUCTION}

Malignant brain tumors constitute one of the most devastating forms of human cancer. Approximately $40 \%$ of all primary brain tumors arise from transformed glial cells and are therefore classified as gliomas. Astrocytomas are a hetereogeneous group of tumors, which range from low grade to high grade anaplastic lesions, including the most aggressive variant, gliomblastoma multiforme (GBM). GBM is a progressive tumor, acquiring genetic mutations as it becomes increasingly aggressive. While primary GBM arises and progresses rapidly to

\footnotetext{
*Address correspondence to this author at the Gene Therapeutics Research Institute, Cedars-Sinai Medical Center; Department of Molecular and Medical Pharmacology and Department of Medicine, David Geffen School of Medicine, UCLA, Research Pavilion, Suite 5090, 8700 Beverly Boulevard, Los Angeles, CA 90048, USA; Tel: 310-423-7303; Fax: 310-423-7308; E-mail: castromg@ cshs.org 
death, secondary GBM develops over time evolving by mutation from lower grade tumor types into GBM. After surgical resection, the incidence of GBM recurrence is high and the mutations found in recurrent GBM differ from those in the primary lesion. Recently, a small fraction of cells found in freshly resected human gliomas have been identified that are $\mathrm{CD} 133^{+}$with stem cell-like properties and these appear to be responsible for the majority of neoplastic tumor growth [Galli et al., 2004; Singh et al., 2004; Tunici et al., 2004; Yuan et al., 2004]. The standard treatment for GBM include surgical debulking of the tumor mass which is accessible to the neurosurgeon, surgical biopsy for pathological diagnosis, chemotherapy and radio-therapy [Castro et al., 2003]. In spite of advances in all these treatment modalities, mean survival after diagnosis and surgical resection alone is approximately six months, with only 7-8\% of the patients surviving for up to two years. Radiation and chemotherapy post-surgery can extend the survival time of these patients for up to nine months to a year [Shand et al., 1999; Burton et al., 2000; Beauchesne 2002; Castro et al., 2003]. Interestingly, recent evidence suggests that subpopulations of glioma patients may exist, based on their survival time post-treatment. Characterization of these patients using gene expression profiling revealed long-term survival differences after conventional treatments that far surpass all expectations, even after using the most modern and aggressive forms of treatment available to date [Rich et al., 2005]. The better surviving gliomas displayed a more differentiated phenotype defined by overexpression of genes involved in neurogenesis [Freije et al., 2004].

Due to the highly invasive nature of GBM, it is impossible for the most skilled neurosurgeon to remove all the tumor mass, usually leaving behind tumor remnants which cause the recurrences leading to the death of the patient (for a recent review of treatments targeting invasion see [Lefranc et al., 2005]). Furthermore, in some instances, the tumor is located in areas of the brain which makes total resection impossible, due to side effects such as neurological deficits and immediate morbidity. Also, increasing the field or dose of radiation therapy will yield unacceptable tissue damage, necrosis, edema and long term neurological deficits.

Due to the limitations of current treatment modalities, efforts are being directed at improving chemotherapeutic agents and more efficient delivery techniques which will improve the diffusion of the drugs through the blood brain barrier and the tumor mass. In addition, novel treatment modalities based on the delivery and expression of therapeutic genes which can induce tumor cell death, inhibit tumor angiogenesis, and induce an effective immune response against the GBM are being very actively pursued. In this review we will cover gene therapy approaches which harness the effects of cytotoxic tumor cell death, caused by either conditional cytotoxic genes, or direct cytotoxic approaches using toxins, in combination with immune stimulatory approaches to induce the generation of an effective systemic immune response against the tumor. These techniques in combination with current treatment modalities will greatly improve the prognosis and extend the lifespan of patients affected with this devastating form of brain cancer.

\section{B. MODELS OF GLIOMA}

The study of tumorigenesis and the evaluation of new therapies requires accurate and reproducible brain tumor animal models, which reduce the exposure of patients to non efficacious or unsafe drugs. Ideally, models of glioma should exhibit key features of the human disease state including glial differentiation of tumor cells, diffuse infiltration, neovascular proliferation, regional necrosis, and resemble progression kinetics and anti-tumor immune responses [Kleihues et al., 1970; Maher et al., 2001].

In vivo tumor models developed after intracranial or subcutaneous implantation of glioma cell lines in rodents are widely used in cancer therapy research. The advantages of these glioma 
models are their highly efficient gliomagenesis, reproducible growth rates and an accurate knowledge of the site of the tumor. Some of the most widely used rat brain tumor models include 9L gliosarcoma, C6 glioma, CNS-1 glioma, F98 glioma, RG2 glioma and RT-2 induced glioma [Barth 1998]. CNS-1, F98 and RG2 glioma cells are excellent sources for brain tumor models, due to their glial phenotype, reproducible in vivo growth rates and histological features that closely resemble human glioma, being nonimmunogenic in syngeneic rats [Kruse et al., 1994] [Tzeng et al., 1991].

Mouse glioma models are also available for brain cancer research. Human glioma xenografts, including SF-295, U-251, D54 and U87, or rat glioma xenografts, such as C6 cells, implanted in immunocompromised mice or rats are extensively used. However, the impairment of immune-mediated events that occur during tumorigenesis and anti-cancer therapies limits their usefulness. Syngeneic mouse models, including GL26 cell [Albright et al., 1975] and GL261 [Akbasak et al., 1991] cell lines, which are nonimmunogenic when injected into C57BL6 mice have shown to be useful for studying the response of brain tumors to immunotherapy [Akbasak et al., 1991]. A recent syngeneic glioma cell line derived from spontaneous tumor in a transgenic animal called 4C8, shows histological features of human gliomas and constitutes a promising animal model for anti-cancer therapy experimentation [Weiner et al., 1999].

To more accurately represent the spontaneous development of glioma, genetically engineered mouse models have also been generated by modifying genes known to be altered in human gliomas. Genetic glioma models have advantages over cell implantation models, in that they mimic molecular and histological features of human brain tumors, as well as the tumorigenic process itself [Lampson 2001]. Although cell implantation allows probing site-specific effects and offers an easy and reliable model to test therapies, genetic glioma models simulate the interactions between the tumor and the surrounding brain tissue as well as the time course of gliomagenesis and progression [Lampson 2001].

Different approaches have been used to develop genetic models of glioma. Germline deletion of the tumor suppressor genes p53 or NF1 were found to increase the susceptibility to astrocytoma and glioblastoma in mice [Reilly et al., 2000]. Deletion of INK4A and ARF, concomitant with the somatic transfer of the receptor tyrosine kinase PDGF into astrocytes and CNS progenitor cells enhances the appearance of mixed oligoastrocytomas and oligodendrogliomas, respectively [Dai et al., 2001]. These reports, not only served as a source of new brain tumor animal models, but also, support the idea that disregulation of the cell cycle has a predominant role in carcinogenesis. In fact, transgenic mice overexpressing the oncogenes v-src and v12H-Ras under the control of the GFAP promoter develop astrocytomas which progression kinetics and histological features resemble the human tumors [Weissenberger et al., 1997] [Ding et al., 2001; Begemann et al., 2002].

\section{TARGETS FOR GENE THERAPY OF GLIOMA}

Preclinical progress using animal models has led to the characterization of potential gene therapeutic approaches for glioma. Conditional cytotoxic approaches introduce noncytotoxic enzymes into the glioma which upon prodrug administration convert the prodrugs into toxic compounds capable of killing tumors. Anti-angiogenic paradigms are designed to prevent the vascularization of tumors which is required for growth and metastasis. Immune stimulatory approaches seek to use the patient's own immune system to target and destroy tumors; this approach ideally also would involve induction of immunological memory to protect against disease recurrence. Targeted toxin strategies utilize receptors specifically overexpressed on glioma cells to target the toxins directly into tumor cells, specifically destroying these cells. Also, tumor suppressor and oncogenes are targets for gene therapy and utilize the genetic abnormalities of the tumor as a therapeutic target. Substantial progress characterizing potential 
treatments preclinically has occurred in all five target areas and will be summarized in subsequent sections.

\section{Replication-Deficient Vectors Encoding Conditional Cytotoxic Genes to Treat Brain Tumors}

In targeting brain tumors with conditionally cytotoxic therapies the goal is to achieve highly specific destruction of tumor cells without toxicity to normal tissue or induction of a systemic immune response against healthy tissues/organs. Conditionally cytotoxic gene therapy delivers an enzyme into tumor cells which is non-cytotoxic until the administration of a likewise, noncytotoxic prodrug. Upon prodrug administration, the therapeutic enzyme converts the noncytotoxic prodrug into a toxic metabolite able to induce cell death.

Initial investigations sought to exploit prodrug activation using endogenous enzymes expressed at higher levels in tumor cells [Connors et al., 1966; Cobb et al., 1969], however; clinical application was limited since such enzymes were expressed in normal cells and only a small number of human cancers had high enough levels of activating enzymes to elicit efficacy in cancer therapy. To overcome these problems, identification of non-mammalian enzyme/ prodrug combinations was undertaken. Use of viruses to specifically target enzymes to tumors has produced promising results in vitro and in vivo.

For therapy to be successful the enzyme must be expressed exclusively within the tumor cells and its catalytic activity be high enough for clinical benefit without toxicity to normal tissue. Since expression will not occur in all tumor cells, a significant bystander effect is essential. Bystander effects occur when the cytotoxic metabolite is transmitted to cells not originally transduced with the enzyme. This may occur via transport through gap junctions or by diffusion through the extracellular space. In addition to delivery of the enzyme, delivery of the prodrug must be delayed sufficiently to allow expression of the enzyme in target cells.

A large number of enzyme/prodrug combinations have been discovered and characterized in brain tumor treatment. The most well characterized conditionally cytotoxic combinations are herpes simplex virus type-1 thymidine kinase (HSV1-TK)/ganciclovir (GCV) and cytosine deaminase (CD)/ 5-fluorocytosine (5-FC). In addition to these well characterized pairings, cytochrome P450/CPA, E. coli purine nucleoside phosphorylase/6-methyl-purine-2'deoxynucleo-side, carboxypeptidase/methotrexate- $\alpha$-phenylalanine have all been under investigation for use in brain tumor treatment (for review see [Aghi et al., 2000; Greco et al., 2001]).

a. Herpes Simplex Virus Type-1 Thymidine Kinase/ Ganciclovir (GCV)—HSV1TK was first developed as a prodrug-activating enzyme by Moolten and has been studied intensively in pre-clinical and clinical studies to treat a wide range of solid tumors [Moolten 1986; Ram et al., 1997]. In addition to wild-type TK, several TK mutants have shown increased TK mediated effects in glioma models [Cowsill et al., 2000; Wiewrodt et al., 2003]. The prodrug GCV, is an acyclic analog of DNA nucleoside 2-deoxyguanosine which HSV1-TK phosphorylates to convert into a toxic DNA analog which triggers tumor cell death.

HSV1-TK/GCV pairing was the first in which bystander effects were described [Freeman et al., 1993]. In murine glioma studies, total tumor regression was observed when at least $10 \%$ of tumor cells were transduced with HSV1-TK [Caruso et al., 1993; Freeman et al., 1993; Chen et al., 1995; Sandmair et al., 2000]. GCV-triphosphate moves between cells via gap junctions [Elshami et al., 1996; Mesnil et al., 1996; Dilber et al., 1997; Touraine et al., 1998] and triggers cell death through cell:cell contact. 
Delivery of HSV1-TK into intracranial tumor has been successfully accomplished using replication-deficient retroviral vectors [Vincent et al., 1996], retroviral packaging cells [Takamiya et al., 1993; Izquierdo et al., 1995; Vincent et al., 1996], HSV vectors [Cobb et al., 1969; Boviatsis et al., 1994; Boviatsis et al., 1994] replication deficient adenoviral vectors [Chen et al., 1994; Perez-Cruet et al., 1994; Vincent et al., 1996], replication competent adenovirus [Nanda, 2001 \#169; Nanda et al., 2001], and adeno-associated vectors [Mizuno et al., 1998; Okada et al., 2001]. Treatment triggered infiltration of CD4+ and CD8+ T cells and macrophages as well as increased expression of a host of cytokines [Perez-Cruet et al., 1994; Vile et al., 1997]. Induction of the immune system resulted in tumor regression locally at the site of HSV1-TK/GCV action and at distant sites in both normal and immuno-compromised animals [Dilber et al., 1996; Wilson et al., 1996; Bi et al., 1997] (Fig. 1). CTL mediated regression of tumors produced long-term immunity to subcutaneous tumors. Likewise, treatment of subcutaneous tumors triggered regression of intracranial tumors even if the intracranial tumor was established before CTL response to the subcutaneous tumor was fully activated [Okada et al., 2001]. While HSV1-TK efficiently destroys tumor cells in the brain, long-term expression of HSV1-TK can result in chronic inflammatory [Dewey et al., 1999; Thomas et al., 2001] responses making the use of regulatable vectors a promising approach. Transduction of cells with HSV1-TK and treatment with GCV renders cells more sensitive to both chemotherapy and radiation suggesting that using multiple treatment modalities will produce more effective tumor regression [Kim et al., 1997; Valerie et al., 2000; Rainov et al., 2001; Nestler et al., 2004]. In addition to combining standard therapies, combining HSV1- TK with immune stimulatory strategies is under investigation and shows promise for more efficient tumor destruction. HSV1-TK has been combined with TNF $\alpha$ [Moriuchi et al., 1998; Niranjan et al., 2000; Niranjan et al., 2003], IL-4 [Benedetti et al., 1997; Okada et al., 2000], Flt3L [Ali et al., 2004; Ali et al., 2005], decorin [Biglari et al., 2004] and connexin 43 [Marconi et al., 2000] to attempt increased efficacy in preclinical GBM models.

b. Cytosine Deaminase/5-Fluorocytosine-As with HSV-ITK, cytosine deaminase (CD) produces a toxic nucleotide analog which triggers cell death. CD is not found in mammalian cells but occurs in bacteria and fungi catalyzing the conversion of cytosine to uracil. When combined with the prodrug 5-fluorocytosine (5-FC), deamination generates 5fluorouracil (5-FU) which ultimately triggers cell death through inhibition of thymidylate synthase. CD/5-FC results in a strong bystander effect that is not cell contact specific [Domin et al., 1993]. Transduction of only 2-4\% of cells resulted in significant regression of tumor as toxic metabolites diffuse freely[Huber et al., 1994; Trinh et al., 1995].

Delivery of CD either by replication-deficient adenovirus, oncolytic adenovirus or retrovirus caused tumor regression of both C6 and 9L rat models of glioma [Ge et al., 1997; Ichikawa et al., 2000; Wang et al., 2003; Conrad et al., 2005]. Areas of necrosis surrounded by apoptotic cells were observed [Ichikawa et al., 2000] as was demylenation and gliosis within areas of normal brain tissue. Both HSV1-TK and CD therapeutics result in apoptosis of cells that is independent of $\mathrm{p} 53$ or death receptors [Kurozumi et al., 2004]. Mitochondrial caspase activation is required in both modalities to induce apoptosis[Fischer et al., 2005]. To increase efficacy combination of CD/5FC with HSV1-TK/GCV results in faster and more complete tumor regression than either single therapy alone [Aghi et al., 1998; Chang et al., 2000]. Likewise CD cytotoxicity is enhanced by radiation therapy although damage to normal brain can also occur requiring strict definition of both therapeutic modalities [Kambara et al., 2002].

c. Cytochrome P450/Cyclophosphamide-Cytochrome P450 converts cyclophosphamide (CPA) into a mustard like toxin which triggers DNA crosslinking and protein alkylation [Dachs et al., 2005]. CPA can be activated by endogenous Cytochrome P450 in human liver requiring monitoring of liver function in studies involving this enzyme prodrug 
combination [Chang et al., 1993]. Cytochrome 450/CPA bystander effects do not require cell contact as metabolites released from the cell can trigger cytotoxicity in cells not directly transduced with cytochrome P450 [Wei et al., 1995]. Intracranial delivery of cytochrome P450 by adenovirus or retrovirus into either 9L or $\mathrm{C} 6$ glioma models resulted in at least a partial regression of tumor and prolonged survival [Wei et al., 1994; Manome et al., 1996]. In addition to CPA, cytochrome $\mathrm{P} 450$ produces cytotoxic effects in glioma cells when other prodrugs are used alone or in combination with CPA [Rainov et al., 1998; Aghi et al., 2000; Huang et al., 2000; Jounaidi et al., 2000; Frank et al., 2002]. Also, chemotherapy combined with cytochrome p450 gene therapy showed greater efficacy than either treatment alone[Chen et al., 1995].

d. E. coli Purine Nucleoside Phosphorylase-E. coli purine nucleoside phosphorylase (PNP) converts nontoxic purine nucleoside analogs into toxic adenine analogs to block both mRNA and protein synthesis. PNP can be combined with multiple prodrugs including 6methylpurine and F-araAMP[Gadi et al., 2003; Parker et al., 2003]. High bystander activity which is cell contact independent may allow widespread tumor death from a relatively small dose of PNP. Delivery of PNP by adenovirus into subcutaneous glioma cells tumors resulted in tumor elimination when only 2-5\% of cells were directly transduced [Hong et al., 2004]. Subcutaneous tumors generated from glioma cells retrovirally transduced to express PNP showed regression upon prodrug administration [Parker et al., 1997; Gadi et al., 2003].

e. Carboxypeptidase G2-Carboxypeptidase G2 (CPG2) is found in bacteria but not humans and removes glutamic acid moieties from folic acid, inhibiting cell growth. When combined with the prodrug [Marais et al., 1996] 4-benzoyl-L-glutamic acid (CMDA), a DNAcrosslinking mustard drug is released [Springer et al., 1990]. Unlike HSV1-TK and CD, catalysis of the prodrug with CPG2 does not require further enzymatic processing to become the final toxic compound. Mustard-alkylating agents are not cell-cycle dependent enabling the killing of proliferating and non-proliferating cells [Springer et al., 2000]. As with other enzyme/ prodrugs, CPG2/CMDA produces a robust bystander effect. Only 10-12\% transduction resulted in 50-100\% killing in vitro or in vivo [Marais et al., 1996; Stribbling et al., 2000]. Replication-deficient adenoviral vector delivery of CPG2 into glioma cells which were resistant to chemotherapeutic drugs and not killed by HSVTK/GCV showed 70\% cell killing [Cowen et al., 2002].

\section{Suppression of Angiogenesis}

Large tumors consist of poorly vascularized but densely packed cells through which nutrients and oxygen do not permeate readily. This environment initially restricts growth of tumors and angiogenesis is required to supply sufficient oxygen and nutrients to tumors to sustain further growth [Singh et al., 2003]. Angiogenesis involves the rapid proliferation of endothelial vascular cells, culminating in the formation of new blood vessels, and is tightly regulated in adults. This regulation is coordinated by the expression of both activators and inhibitors of angiogenesis. As tumors increase in size, a need arises for vascularization within the tumor mass before further growth can occur. Therefore, a selective pressure is placed on the tumor cells to alter the expression of promoters and inhibitors of angiogenesis and in doing so to stimulate the development of new vasculature.

Glioblastoma is among the most highly vascularized of all tumors; acquiring the ability to promote angiogenesis is a critical step in the progression of a tumor from a benign, microscopic lesion to a malignant macroscopic cancer. Consequently, angiogenesis has received much attention as a potential therapeutic target. These therapies are expected to have few serious side effects because angiogenesis in healthy adult humans usually only occurs in response to pathological insults from wounds or hypoxia. Several of these angiogenic inhibitors have been shown to reduce tumor growth in vitro and in vivo [Kirsch et al., 2000]. However, a number 
of disadvantages limit the potential of angiogenic inhibitors in clinical setting. First, production of sufficient quantities of angiogenic inhibitors is expensive limiting the availability of these drugs in clinical trials. Synthetic small molecule inhibitors of angiogenesis are being developed to overcome this problem [Sebti et al., 2000] but the side effects of these drugs are unknown. Second, angiogenic inhibitors are believed to be cytostatic, not cytotoxic requiring long-term treatment to control and ultimately reduce tumor size [Kirsch et al., 2000]. Third, toxic side effects have been observed with systemic delivery of some angiogenic inhibitors [Puduvalli et al., 2000]. Gene therapy offers distinct advantages to deliver clinically effective doses of angiogenic inhibitors to the tumor and has been successfully employed in the treatment of a variety of tumors in preclinical studies [Chen et al., 2001].

a. Targets That Promote Angiogenesis-The first growth factor identified as a positive regulator of angiogenesis was basic fibroblast growth factor (bFGF) [Montesano et al., 1986] and increased expression of bFGF correlates with progression of a wide variety of solid tumors [Szabo et al., 1998]. Adenoviral gene transfer of bFGF was found to promote angiogenesis in rat brains [Yukawa et al., 2000]. However, a clear correlation between increased bFGF expression and glioma progression has not been demonstrated in glioma suggesting that $\mathrm{bFGF}$ is not the principle mediator of angiogenesis [Markert et al., 2000]. Another promoter of angiogenesis called vascular endothelial growth factor (VEGF) was found to be overexpressed in high grade gliomas [Plate et al., 1995]. Expression of the receptors for VEGF, Flt-1 (VEGFR-1) and Flk-1 (VEGFR-2), are also elevated in glioblastoma in comparison with surrounding normal tissue and Flk-1 in particular is believed to promote angiogenesis in response to VEGF [Stratmann et al., 1997]. Transfection of anti-sense VEGF cDNA into rat glioma C6 cells in vitro impaired C6 tumor cells growth in comparison to controls when subsequently implanted into nude mice [Saleh et al., 1996]. Recombinant viruses have also been used to transfer anti-sense VEGF cDNA sequence and rats with intracranial neoplasms showed a statistically significant improvement in survival when treated with this retrovirus [Sasaki et al., 1999]. A VEGF receptor that displays dominant negative function when overexpressed in cells has also been developed and was expressed by a retrovirus. Survival was successfully prolonged in rats with intracranial tumors and these tumors displayed many classical signs of impaired angiogenesis including reduced vascular density and elevated necrosis [Machein et al., 1999; Heidenreich et al., 2004]. Urokinase Plasminogen activated receptor (uPAR) and Cathepsin B are also overexpressed during glioma progression and have been implicated in promoting angiogenesis. Adenovirus expressing anti-sense uPAR and Cathepsin B and injection of plasmid DNA encoding siRNA sequences targeting uPAR and Cathepsin B inhibit glioma growth, invasion and angiogenesis [Gondi et al., 2004; Gondi et al., 2004].

b. Targeting Inhibitors of Angiogenesis-The relatively low percentage of cells transduced by recombinant viral vectors is a limiting factor in inhibiting targets which promote angiogenesis. Inhibitors of angiogenesis overcome this problem and have been the subject of numerous pre-clinical studies. Many naturally occurring inhibitors of angiogenesis are derived from proteolytic degradation of the extracellular matrix. Endostatin and angiostatin are generated following the proteolytic cleavage of plasminogen and collagen respectively and are potent inhibitors of angiogenesis [O'Reilly et al., 1994; O'Reilly et al., 1997]. These peptides are difficult to generate in sufficient quantities in vitro, and thus are ideal candidates as transgenes for gene therapy. Recombinant viral vectors that express endostatin [Yamanaka et al., 2001; Peroulis et al., 2002] or angiostatin [Tanaka et al., 1998; Ma et al., 2002] have been developed and tested in preclinical models of glioma. Improved survival of animals with intracranial neoplasms was observed in all cases and tumor growth rates were reduced by as much as $90 \%$. Other anti-angiogenic protein fragments have also been studied for effectiveness in animal models of glioma and these include soluble human platelet factor 4 and the $\mathrm{N}$-terminal 
fragment of rat prolactin. It appears that these trans-genes are not as effective as endostatin and angiostatin in significantly improving survival [Tanaka et al., 1997; Witte et al., 2002]. A number of proteins associated with immune system function also have anti-angiogenic properties. IL-4 and interferon gamma have been studied in rat models of glioma [Saleh et al., 1999; Saleh et al., 2000] with improved survival and reduced angiogenesis and tumor growth rates. However, the principal function of these transgenes is in recruiting and modulating various cellular and humoral aspects of the immune response and will be dealt with in the following section.

\section{Immune Stimulation}

Histological analysis of tumors reveals that an immune response is often elicited against the tumor. Inflammation, and even tumor-specific lymphocytes are often evident, and in some rare cases, tumor regression spontaneously occurs in response to autoimmune paraneoplastic syndromes [Nagel et al., 1971; Darnell et al., 1993]. This is believed to be caused by tumor specific antigen expression and underscores a role for the immune system in cancer immunosurveillance and control of disease progression. Unfortunately, most tumors develop counter measures that hamper an effective immune response developing against the growing tumor. As a result, there is significant interest in developing immunotherapies to improve the response of the immune system to the tumor. Gene therapy offers numerous different mechanisms to stimulate an immune response against tumors. We shall briefly outline progress in the four most promising areas.

a. Tumor Antigens Delivered through Adenoviral Expression-Most if not all tumors express proteins that are recognized by the immune system and are called tumor antigens. Adenoviral vectors can be engineered to express these antigens as transgenes and subsequently used to prime an immune response against that target antigen if injected systemically. Promising results from preclinical trials have been reported for renal cell carcinoma among others, where adenovirus expresses the tumor antigen carbonic anhydrase IX protein [Jongmans et al., 2003]. However, it is unclear whether this approach would be effective for mounting an effective immune response against gliomas.

b. Enhancement of the Immune Response Using Interferons-Interferons secreted ligands involved in immunity and inflammation. They are potentially valuable targets in gene therapy due to the highly specific immune-stimulatory function of many of these molecules. Type I interferons, including IFN- $\alpha$, IFN- $\beta$ and IFN- $\omega$ are produced primarily by a specialized population of dendritic cells in response to viral infection and other immune modulators. IFN$\alpha$ has been shown to elicit numerous anti-tumor effects including inhibition of cell cycle progression, induction of apoptosis and stimulation of the immune system to destroy tumor cells [Kemp et al., 2003; Tosi et al., 2004]. In addition, treatment of human glioblastoma cell lines with IFN- $\alpha$ increased cell surface expression of MHC-1 [Yang et al., 2004]. Intramuscular delivery of plasmid DNA encoding IFN- $\alpha$ significantly reduced the tumor volume in a mouse model of glioma when compared with control animals [Horton et al., 1999]. IFN- $\alpha$ also promoted regression of intracranial gliomas when co-delivered with dendritic cells directly into the tumor mass [Tsugawa et al., 2004]. Another type I interferon called IFN- $\alpha$ provides systemic anti-tumor immunity against GL261 cells when delivered intracranially. This reduces tumor growth and improves survival in C57 BL6 mice through a combination of antiproliferative effects and also the activation of $\mathrm{CD} 8^{+}$but not $\mathrm{CD} 4^{+}$cells [Natsume et al., 2000]. In another report, combination of IFN- $\alpha$ and dendritic cells was found to suppress tumor growth. This was mediated by a highly effective CTL response against the tumor and was far more efficient that either therapy alone [Nakahara et al., 2003]. An adeno-associated virus designed to deliver this transgene has also been developed and completely inhibits growth of 
exogenous human tumor xenografts in nude mice, further supporting the potential of IFN- $\alpha$ as a novel therapy for treating human glioma [Yoshida et al., 2002].

c. Enhancing T Cell Activation-A number of cytokines are believed to activate various subclasses of T lymphocytes. For example, IL-12 is required for the anti-tumor $\mathrm{T}_{\mathrm{H}} 1$ type pattern of differentiation in naïve mature T lymphocytes. Adenovirus expressing IL-12 has been reported to enhance the immune response to brain tumors and improve survival in mice inoculated with GL26 glioma cells intracranially. Increased CD4 ${ }^{+}$and increased CD8 ${ }^{+} \mathrm{T}$ cells were identified at the tumor site [Liu et al., 2002]. Recently, allogenic cells genetically engineered to secrete IL-2, were found to significantly improve survival in a mouse glioma model. The immune response was found to be predominantly mediated by $\mathrm{CD} 8^{+}$and natural killer cells (NK) and was highly specific for the glioma cells above nonneoplastic cells [Lichtor et al., 2003].

d. Mobilizing Dendritic Cells-It is believed that dendritic cells are the principal antigen presenting cells of the immune system and are required for the development of an antigendependent immune response. Dendritic cells differentiate from precursor cells in response to Flt3L expression through a STAT3 dependent mechanism [Laouar et al., 2000]. Expression of Flt3L has been demonstrated to induce complete tumor regression and significantly improve survival [Lynch et al., 1997]. Furthermore, dendritic cells are highly effective inducers of tumor specific killer and helper T lymphocyte generation in animal models of tumors [Schuler et al., 2003]. Therefore, interest has been generated surrounding the use of dendritic cells and Flt3L in immunotherapy.

Dendritic cells are absent from the brain parenchyma except under conditions of inflammation and it is believed that this a major reason for immune privilege of the brain [McMenamin 1999; Fischer et al., 2000; Serafini et al., 2000; Fischer et al., 2001; Santambrogio et al., 2001; Lowenstein 2002]. This places spatial limits on the ability of dendritic cells to migrate to intracranial tumors. One strategy for circumventing this problem is to deliver dendritic cells directly into the intracranial tumor mass [Tsugawa et al., 2004]. Another solution is to pulse dendritic cells with glioma antigen in vitro, before re-administering these cells in the periphery [Heimberger et al., 2000]. Unfortunately, manipulation of dendritic cells in vitro may reduce the effectiveness of the therapy by inducing unwanted side effects. Our group has developed an alternative strategy, utilizing an adenoviral vector expressing the dendritic cell growth factor, Ft3L, and have used this approach to successfully treat both microscopic and macroscopic models of glioblastoma in a syngeneic rat model [Ali et al., 2004; Ali et al., 2005] (Fig. 2). Adenoviral vectors are delivered directly into the tumor mass and cause a potent, anti-tumor immune response resulting in the rejection of the tumor in $60-80 \%$ of animals where all other therapies tested fail [Ali et al., 2005]. Depletion of either $\mathrm{CD}^{+} \mathrm{T}$ cells or macrophages caused the therapy to fail completely, suggesting that by presenting antigen to $T_{H}$ cells, DC's primed a potent anti-tumor immune response (Fig. 3). This data highlight the promise of immuno-therapies in greatly enhancing the efficacy of current therapies and the potential of curing the disease.

\section{Targeted Toxins}

Several cellular receptors are exclusively overexpressed on brain tumor cells have been used to target anti-cancer therapy. Human gliomas in situ overexpress several membrane molecules, including variants of the IL-13 receptor, IL13R $\alpha 2$ [Debinski et al., 1999; Debinski et al., 2000; Li et al., 2002; Todhunter et al., 2004], the urokinase-type plasminogen activator (uPA) receptor [Mori et al., 2000; Todhunter et al., 2004] and the epidermal growth factor (EGF) receptor [Phillips et al., 1994; Liu et al., 2005]. These receptors are virtually absent in the normal brain; thus, they have been targeted in preclinical and clinical trials for the treatment 
of brain tumors, with minimal side effects to normal brain tissue. Natural ligands of IL13R $\alpha 2$, uPA receptor and EGF receptor, i.e., IL-13, uPA and EGF/transforming growth factor $\alpha$ (TGF- $\alpha$ ), respectively, have been fused to the catalytic and translocation domains of highly cytotoxic bacterial products, such as Pseudomonas [Phillips et al., 1994; Debinski et al., 1995] and Diphteria exotoxins [Mori et al., 2000; Liu et al., 2002; Todhunter et al., 2004; Liu et al., 2005]. These fusion toxins have shown to be selectively internalized by glioma cells. Once internalized the toxins inhibit protein synthesis, which induces cell death of the targeted cell without affecting normal brain cells. In vitro and in vivo experiments in murine glioma models have shown the high efficacy and low toxicity of these approaches [Phillips et al., 1994; Debinski et al., 1995; Mori et al., 2000; Liu et al., 2002; Todhunter et al., 2004; Liu et al., 2005].

IL-13 is a cytokine that binds in normal cells to a heterodimeric receptor complex composed of IL-13 receptor and IL-4 receptor. Although this receptor is widely expressed in normal peripheral tissues, it is virtually absent in normal brain tissue [Abramovitch et al., 1995; Mintz et al., 2002]. However, IL-13 binds with high affinity to glioma cells [Debinski et al., 1995; Debinski et al., 1996] due to the overexpression of IL-13R $\alpha 2$, a restricted monomeric receptor with affinity for IL-13, but not for IL-4 [Debinski et al., 1999; Debinski et al., 2000; Debinski et al., 2000; Mintz et al., 2002; Liu et al., 2003; Mintz et al., 2003]. This feature of IL-13R $\alpha 2$ can be used as a therapeutic target for GBM.

Pseudomonas exotoxin is a cytotoxic bacterial protein which encompasses three functional domains. Domain I binds the $\alpha_{2}$-macroglobulin receptor, which is ubiquitously expressed in normal tissues, and the exotoxin- $\alpha 2$-macroglobulin receptor complex undergoes receptormediated endocytosis [Pastan et al., 1992]. Domain II is a site of proteolytic cleavage that activates the resulting exotoxin and is necessary to catalyze the translocation of the toxin into the cytosol. Domain III directs the processed fragment of the toxin to the endoplasmic reticulum and possesses an ADP ribosylation activity that inactivates elongation factor 2, inhibiting protein synthesis and leading to cell death [Pastan et al., 1992] (Fig. 4). The mutant exotoxin, PE38QQR (PE), does not bind to the ubiquitous $\alpha 2$-macroglobulin receptor due to the deletion of domain I [Debinski et al., 1994], and can be linked to various ligands in order to promote its internalization into target tumor cells. In order to target the PE toxin to human glioma cells, a fusion protein was developed by linking the mutated form of Pseudomonas exotoxin to hIL-13 throughout its N-terminal domain, to generate hIL-13-PE [Debinski et al., 1995]. This recombinant protein, also termed IL-13 toxin, is cytotoxic to human glioblastoma cells expressing the IL-13 $\alpha 2$ receptor in culture [Debinski et al., 1995; Debinski et al., 1995; Liu et al., 2003] and in human xenograft glioma cells implanted in the flank of nude mice [Husain et al., 2001]. The targeting of IL-13 $\alpha 2$ receptor has been improved by the engeneering of the human IL-13 gene, leading to a mutated IL-13 toxin with higher cytotoxicity and affinity for the IL-13 $\alpha 2$ receptor when compared to the wild type IL-13 toxin [Debinski et al., 1998;

Madhankumar et al., 2004]. The fusion of this muIL-13 to PE resulted in an even more active cytotoxin on glioma tumors both in vitro and in vivo with negligible affinity to IL-13 receptor of normal cells [Debinski et al., 1998]. Intratumoral administration of IL13-PE toxin into intracranial human glioma xenografts in mice showed highly cytotoxic effects without undesirable side effects [Kawakami et al., 2004].

\section{Tumor Suppressors and Oncogenes}

All cancerous cells were originally derived from normal precursors. However, cancerous cells harbor harmful mutations in key genes, either tumor suppressors or oncogenes, which regulate proliferation and/or apoptosis. It is widely accepted that tumorigenesis is a multi-step process that requires mutations in many different genes in the DNA of an individual cell, such as genes that promote cell cycle progression, growth factor independence, angiogenesis, increased 
motility, anchorage independence, decreased levels of apoptosis and reduced sensitivity to chemotherapeutic agents. The genetics of gliomagenesis is well characterized in comparison with other cancers and this information can be used to develop gene therapy that repairs these genetic aberrations. Mutations in four pathways in particular are commonly associated with glioma formation in humans; the P53/ARF/human MDM2 pathway, the P16/Rb/cyclinD/ CDK4 pathway, the receptor tyrosine kinase (RTK)/Ras pathway and the PI3K/PTEN/Akt pathway [Merlo 2003]. Viral vectors have been designed that express transgenes commonly mutated in glioma in an attempt to correct the genetic mutations.

a. Tumor Suppressors : p53-P53 is often referred to as "the guardian of the genome" and is mutated or absent in over $50 \%$ of all human tumors. Other proteins known to regulate P53 expression such as c-Jun and MDM2, and downstream effectors of p53 including P21 and $\mathrm{E} 2 \mathrm{~F} 1$ are also frequently mutated in cancer. In fact, mutations in components of the p53 pathway are believed to occur in $>90 \%$ of all human tumors, including human gliomas. The principal role of $\mathrm{p} 53$ as a tumor suppressor is to detect gross genetic abnormalities during DNA synthesis. Expression of p53 is absent in quiescent cells but is expressed in cells during cell cycle progression or in response to genotoxic insults. Once a genetic abnormality has been detected, p53 arrests cell cycle progression and monitors the tumor repair process. If the DNA damage is too great, p53 may induce apoptosis. This altruistic behavior is vital to the collective well being of the organism and greatly reduces the frequency of tumor formation.

Allelic loss of chromosome 17p or mutations in p53 gene are observed with equal frequency in low grade gliomas and high grade glioblastomas [Louis 1994] suggesting that inactivation of p53 occurs early during gliomagenesis and may be an important target for gene therapy. Reintroduction of wild-type p53 into glioma with p53 mutations has been the subject of intense scientific research. Early results suggested that the re-introduction of p53 reduced the proliferation of glioma cells in vitro and suppressed tumor formation when implanted into nude mice [Asai et al., 1994]. Adenovirus expressing p53 was later demonstrated to reduce tumor volume by $40 \%$ over 14 days in rats, [Badie et al., 1995; Kock et al., 1996]. P53 as a therapeutic transgene is not limited to glioma that have lost P53 function. Overexpression of p53 using viral vectors improved survival against challenge with wild type p53 expressing glioma cell lines, indicating a versatile function for this transgene in treating all forms of glioma [Li et al., 1999]. P53 overexpression increases the sensitivity of drug and radiation resistant glioma cell lines to cisplatin and radiotherapy in vitro [Gjerset et al., 1995] and adenovirus expressing p53 restored the sensitivity of 9L glioblastoma cells to cisplatin [Dorigo et al., 1998] and radiotherapy [Badie et al., 1998] in pre-clinical models of glioma. P53 increases the expression of numerous apoptotic proteins in cells, including BAX activators Bim and DP5, and the death receptor ligand FasL. In a recent study, adenoviral vectors expressing p53 under the control of the CMV promoter were demonstrated to induce significant levels of apoptosis as measured by DNA ladder when injected intracranially into the tumor. Furthermore, a 100\% survival rate was observed in these animals 100 days following viral injection [Cirielli et al., 1999]. A number of downstream effectors of $\mathrm{p} 53$ such as $\mathrm{P} 21, \mathrm{E} 2 \mathrm{~F} 1$ and $\mathrm{P} 16$ have also shown promising results in pre-clinical glioma models [Chen et al., 1996; Fueyo et al., 1998]. In fact, vectors expressing P16 and P21 were more effective than P53 at improving survival [Wang et al., 2001], although this has yet to be validated in human clinical trials.

An alternative strategy was originally conceived by Bischoff JR and others and takes advantage of the anti-viral properties of p53. The human AdE1B gene is expressed during adenovirus infection and codes for the $55 \mathrm{kDa}$ protein that binds with and inactivates p53. E1B is essential for a successful viral replication cycle within the host cell and adenoviruses lacking the E1B gene are unable to replicate inside cells expressing normal p53. These recombinant viral particles have since been named ONYX-015 and were cytopathic against p53-deficient human 
tumor cell lines implanted in nude mice [Bischoff et al., 1996; Heise et al., 1997]; [Geoerger et al., 2003].

b. Rb Pathway-The $\mathrm{P} 16 / \mathrm{Rb} /$ cyclinD/CDK4 pathway is the most frequently mutated pathway in glioma, and mutations generally characterize a transition from low-grade tumors with relatively slow rate of proliferation to intermediate-grade gliomas with dramatically increased cell proliferation [Maher et al., 2001]. In normal quiescent cells, $\mathrm{Rb}$ is present in a hypophosphorylated form and is bound by the transcription factor E2F1. This prevents transcription of genes important for mitosis and prevents progression of the cell through the G1/S phase restriction point [Sherr 1996]. In gliomagenesis, allelic losses on chromosome 9q or 13q, or amplification of 12q usually accompany transition of glioma from low grade to intermediate grade [Schmidt et al., 1994; Ueki et al., 1996]. This was later found to correspond with loss of Rb (13q14), loss of INK4A and ARF (9p21), or amplification of CDK4 (12q13-14). Adenovirus mediated $\mathrm{Rb}$ gene therapy has been successfully used in pre-clinical models of glioma, where it was found to decrease the proliferation of spontaneous pituitary tumors in $\mathrm{Rb}^{+/-}$mice and prolonged survival of animals [Riley et al., 1996]. In a similar strategy to ONYX-15, a recombinant adenovirus lacking AdE1A (Delta24) can only replicate in cells expressing phospho-RB and is preferentially cytotoxic to glioma cells. A single injection of Delta24 reduced growth of flank tumors by $66 \%$, and multiple injections reduced tumor growth by $84 \%$ [Fueyo et al., 2000].

More recently, substantial research has also investigated the potential of $\mathrm{P} 16^{\mathrm{INK} 4 \mathrm{~A}}$ to reduce tumor proliferation and improve survival in rodent models of glioma. P16 ${ }^{\mathrm{INK}} 4 \mathrm{~A}$ inhibits $\mathrm{Rb}$ phosphorylation and is mutated in more than 50\% of glioblastomas [Lee et al., 2000]. $\mathrm{P} 16^{\mathrm{INK} 4 \mathrm{~A}}$ expressing vectors were demonstrated to improve survival in animal models of glioma, even when compared with P53 expressing vectors [Wang et al., 2001]. In spite of these promising results, caution is warranted with all therapies designed to repair common genetic lesions in glioma. In a recent report, $\mathrm{P} 16^{\mathrm{INK} 4 \mathrm{~A}}$ was expressed in glioma cell lines under the control of the Tet repressor system. Elevated P16 $6^{\mathrm{INK} 4 \mathrm{~A}}$ reduced tumor proliferation in vivo initially, supporting work published by others. However, long term transgene expression induced a decrease in the expression of Rb suggesting that gene therapy approaches involving P16 ${ }^{\mathrm{INK} 4 \mathrm{~A}}$ may ultimately lead to the selection of Rb deficient tumors [Simon et al., 2002]. In fact, this is a potential problem of all approaches designed to correct genetic lesions in cancer. Tumor cells are genetically unstable and undergo accelerating genetic mutation. Unfortunately, this accelerates natural selection and will select for tumor cells that overcome this transgene insertion. The possibility of tumor cells compensating for transgene insertion through one or more subsequent mutations must be explored in all promising therapies that repair the primary genetic lesion in cancer.

\section{CLINICAL TRIALS OF GENE THERAPY FOR GLIOMA}

GBM treatment involves surgical resection combined with chemotherapy and radiotherapy. Even with aggressive therapeutic approaches mean patient survival from initial diagnosis has remained at nine to twelve months for over 5 decades. Numerous gene therapy approaches have moved from preclinical studies to clinical trials with the goal of delivering gene-based therapeutics into the tumor mass to trigger tumor elimination and long standing protection against recurrence.

Multiple approaches to specifically target brain tumor cells have been developed and will be discussed. Conditional cytotoxicity delivers non-cytotoxic therapies into tumor cells where upon administration of a prodrug, cytotoxic metabolites are produced which trigger tumor cell death. Targeted toxins specifically deliver toxins like pseudomonas endotoxin or diphtheria toxin into tumor cells by targeting receptors upregulated only on tumor cells. Oncolytic viruses 
cause tumor cell lysis and viral spread after infection by specifically infecting tumor cells with genetic/metabolic alterations relative to normal tissue.

Delivery of therapeutics into the brain poses a significant challenge in the development of novel treatments for GBM where in addition to having to target a large tumor mass or resected tumor cavity, the neurosugeon encounters the bone structure of the cranium and the blood brain barrier. The use of convection enhanced delivery (CED) may presently represent the best option to achieve safe widespread distribution of the therapeutic vectors/compounds. By this method several catheters are placed within the target brain area and infusion of the therapeutic is conducted at a continuous and slow rate. CED has been particularly successful in clinical trials utilizing targeted toxins [Qureshi et al., 2000; Saito et al., 2004].

\section{Conditional Cytotoxicity}

The majority of brain tumor related clinical trials utilize viral vectors delivering a Herpes Simplex virus type 1 thymidine kinase (HSV1-TK) gene (mechanism of action described above). To date clinical trials using HSV1-TK to transduce brain tumors have been completed using liposomes, replication-deficient retrovirus producing cells or replication-deficient adenoviruses.

Retroviruses selectively target actively dividing cells making them an attractive vector in the brain where tumor cells are the only rapidly dividing cells. However low titers and unstable virus particles have required the use of virus producing cells (VPCs) instead of direct viral injection into brain [Short et al., 1990; Ram et al., 1997; Rainov et al., 2003]. VPCs continuously produce replication-deficient retrovirus vectors with a very low risk of wild-type virus production from recombination events. VPCs are short lived vector producers incapable of migration, limiting their usefullness [Rainov et al., 2003].

Phase one/two clinical trials to determine maximum tolerable dose (MTD) and toxicity of VPCs producing retroviruses expressing HSV1-TK in treatment of brain cancer have been extensively performed. Most studies involve implanting VPCs into the cavity of resected tumors. After VPCs implantation, virus diffused into surrounding tissue and ganciclovir was administered; patients were evaluated for survival and toxicity [Izquierdo et al., 1996; Ram et al., 1997; Klatzmann et al., 1998; Shand et al., 1999; Packer et al., 2000; Rainov et al., 2000; Prados et al., 2003]. VPCs in small tumors produced anti-tumor effects [Izquierdo et al., 1996; Ram et al., 1997] and individual case studies showed increased immune response following treatment [Izquierdo et al., 1996; Floeth et al., 2001; Kramm et al., 2002]. In general however, survival increases were marginal and limited to a small number of the total patients treated in a trial. Bystander and tumor transduction rates were considerably lower than that observed in preclinical studies [Izquierdo et al., 1997; Ram et al., 1997; Harsh et al., 2000]. The MTD was not determined as all doses used were well tolerated. Concerns for safety resulted in evaluation of anti-virus antibody titers as a systemic immune response to the virus could cause a life threatening situation. While some studies show no change, others showed a small number of patients with increased antibody titers [Ram et al., 1997; Shand et al., 1999], however, no systemic effects caused by the treatment were observed. Evaluation of peripheral blood lymphocytes for wild-type or replication-deficient therapeutic virus showed low or transient presence of therapeutic virus and no wild-type virus outside of the brain [Long et al., 1998; Long et al., 1999]. To evaluate survival, a larger randomized controlled trial was conducted once safety and toxicity had been established. A randomized controlled, multicenter trial involving 248 patients found that while VPC-expressing therapeutic vectors were safe, no significant difference in survival was evident [Rainov 2000] requiring further refinement of treatment strategies to reproduce the preclinical effects observed in a clinical setting. 
To increase clinical efficacy, combinations of HSV1-TK with immune stimulatory factors have also reached clinical trial stages. VPCs expressing both Interleukin 2 and HSV1-TK and Interleukin 4 and HSV1-TK have been injected into patients [Colombo et al., 1997; Palu et al., 1999; Okada et al., 2000]. Results combining IL-2 and HSV1-TK indicate that the treatment is safe and causes increased infiltration of immune cells and tumor necrosis [Palu et al., 1999].

Adenoviral vectors are non integrating, nonenveloped viruses which express transgenes at high levels, are producible at high titers, and infect both dividing and non-dividing cells. Studies comparing either retrovirus producing cells and replication deficient adenoviral vectors' efficiency in transducing human glioma tumors found higher gene transfer efficiency and greater survival times with replication deficient adenoviral vectors [Puumalainen et al., 1998; Sandmair et al., 2000].

Phase one trials using replication deficient adenovirus to deliver HSV1-TK into resected tumor beds or intratumorally followed by ganciclovir administration have established that no systemic toxicicty occurs when viral vector administration remain below $10^{12}$ viral particles [Trask et al., 2000; Smitt et al., 2003]. When $2 \times 10^{12}$ vp were injected intratu-morally, toxicity with confusion hypoatremia and seizures resulted. Post mortem tumors examined following treatment show areas of necrosis and infiltration of macrophages and lymphocytes consistent with an immune response to the tumor [Trask et al., 2000].

The primary concern in the use of adenovirus is a systemic immune response to the virus, since the majority of adults have been exposed to and have mounted an immune response to wildtype adenovirus. No systemic or local symptoms consistent with overt inflammatory processes were observed [Trask et al., 2000; Germano et al., 2003; Smitt et al., 2003]. Likewise, while increased anti-adenoviral vector antibodies were reported in some patients, no symptoms associated with this increase were reported [Sandmair et al., 2000; Germano et al., 2003; Immonen et al., 2004].

With promising results from toxicity studies, a randomized controlled study was conducted involving 36 patients injecting replication-deficient adenovirus into the tumor bed following tumor resection. Mean survival time of adenoviral treated patients was 70.6 weeks compared to 39 weeks with controls [Immonen et al., 2004]. While not curative, these results are statistically significant and very encouraging.

With the concerns of immunogenecity and inflammation associated with the use of viral vectors for gene therapy, development of non viral vectors to deliver therapeutic genes has also lead to clinical trials. In a phase I/II study of the safety and MTD using liposome mediated delivery of HSV1-TK in patients with recurrent glioma, no systemic side effects or immune response associated with the treatment were observed. HSV1-TK cDNA was detectable in cells up to 70 days after infusion. While treatment was not curative, tumor regression was observed in a majority of patients [Voges et al., 2003]. In addition to HSV1-TK delivery, clinical trials are underway to deliver interferon $\beta$ to brain tumors utilizing liposome technology [Yoshida et al., 2004].

\section{Targeted Toxins}

The ability to deliver targeted therapeutics to treat brain tumors is highly desirable to limit the toxic side effects of novel therapies. Specificity in gene therapy can be achieved with the use of targeted toxins. Utilizing biological features unique to tumor cells, delivery of cytotoxic substances can be refined. By, selectively targeting receptors expressed at high levels on tumor cells, vectors can then carry a toxin into the cell to trigger tumor specific cell death. 
a. IL-13 Receptor-The interleukins, a class of cytokines, are produced by T cells and mediate immune system activation acting on nearly all immune cell types. To target glioma cells while sparing normal brain tissue, chimeric IL-13 with mutated Pseudomonas endotoxin (PE) [Pastan et al., 1992] has been utilized in clinical trials. Upon binding to the IL-13 $\alpha 2 \mathrm{R}$, receptor-mediated endocytosis occurs and the toxin translocates to the cytosol to ultimately trigger cell death [Pastan et al., 1992].

Phase I/II studies to determine MTD and toxic effects utilizing IL-13 targeted cytotoxin have been reported and are in progress with patients diagnosed with recurrent malignant glioma [Weingart et al., 2002; Prados et al., 2003]. Intratumoral infusions by convection-enhanced delivery caused steroid responsive edema in 1 out of 3 patients. Dose escalation studies have not yet identified a MTD [Kunwar 2003]. The histologically effective concentration defined as the concentration required to produce $90 \%$ cell necrosis after infusion of the treatment also remains to be determined. Decreased tumor burden and prolonged patient survival is reported in these ongoing trials [Kunwar 2003; Prados et al., 2003].

b. IL-4 Receptor-Interleukin 4 (IL-4) is produced by activated T cells, mast cells and basophils and acts synergistically in the early stages of hematopoesis and B cell activation [Paul 1991; Puri 1995]. As with IL-13, linkage to the cytotoxin PE by replacing the binding domain of PE with IL-4 enables targeted killing of IL-4R expressing cells [Pastan et al., 1992; Puri et al., 1996].

In phase I testing in patients with recurrent malignant glioma, were treated with convection enhanced delivery of cpIL4-PE using doses based on preclinically efficient dosages to determine toxicity in humans [Rand et al., 2000]. Following infusion increased intracranial pressure and edema were observed in most of those treated however it caused no permanent neurological deficits and responded to treatment. No other systemic toxicity was noted and biopsy of the treated area showed no toxicity to normal brain. Increased survival was observed.

No systemic effects were observed in phase II studies to determine the MTD and therapeutic volume [Weber et al., 2003; Weber et al., 2003]. IL-4 cytotoxin was not detectible outside of the CNS however increased IgG antibodies to PE were measured. In ongoing trials, a MTD and increased survival have yet to be observed.

c. TGFa-While expressed at low levels on normal brain, epidermal growth factor receptor (EGFR) is often overexpressed in malignant gliomas. Transforming growth factor alpha (TGF $\alpha$ ) binds to EGFR. As with IL-13 and IL-3, TGF $\alpha$ replacement of the PE binding domain may allow destruction of brain tumors by selectively targeting the overexpressed receptor present only on tumor cells[Sampson et al., 2003].

In phase I trials TP-38 (TGF $\alpha$-PE) was evaluated for toxicity and MTD[Sampson et al., 2003]. TP-38 was infused into brain tumors and corticosteroids were administered up to 72 hours after infusion to prevent edema. While no systemic toxicity was observed, seizure, headache, neuropathy, fatigue, and visual and speech problems were observed, all of which resolved. MTD was not determined during the study. While overall survival was not different between all patients in the study, 3 of 15 patients showed decreased tumor burden.

d. Transferrin Receptor-Transferrin receptors mediate iron transport into cells and are increased on rapidly dividing cells with increased iron requirements [Recht et al., 1990]. Tumor cells including glioma have increased levels of transferrin receptor on their cells surface .

Diphtheria toxin (DT) is a multiple subunit protein composed of binding and catalytic domains [Greenfield et al., 1987; Johnson et al., 1989]. The catalytic subunit catalyzes the addition of 
adenosine diphosphateribose onto elongation factor 2 to inhibit protein synthesis and kill cells. Replacement of the binding subunit with transferrin alters the binding specificity and carries DT into glioma cells. An additional mutation (CRM107) decreased nonspecific binding.

Phase I clinical trial of Tf-CRM107 was completed to determine toxicity and MTD [Laske et al., 1997]. Patients with recurrent malignant brain glioma were infused with the TF cytotoxin, antibiotics and dexamethasone. The MTD was determined to be $0.67 \mathrm{ug} / \mathrm{ml}$ in a $40 \mathrm{ml}$ total infusion volume. Transient increased intracerebral pressure was observed and treated. At the MTD, no local toxicity was observed. No systemic toxicity was observed although transient elevation in serum transaminases and mild hypoalbumnemia were observed. Survival increased from 36 weeks in non responders to 74 weeks in responding patients.

Phase II clinical trial of Tf-CRM107 was undertaken to further study the safety and efficacy of treatment [Laske et al., 1997; Weaver et al., 2003]. Forty four patients enrolled in the study. Infusion related edema and seizures were reported both of which responded to therapy. While all patients entered the study in a progressive disease state, $48 \%$ of patients saw disease arrest at the time of evaluation and $30 \%$ survived beyond one year.

\section{Tumor Suppressors and Oncogenes}

P53 - In addition to delivery of HSV1-TK, adenoviral vectors have been used to deliver p53 into brain tumors. The p53 gene is critical to normal cell cycle and apoptosis. In human glioma, mutation of $\mathrm{p} 53$ or its inactivating proteins are the most frequently found genetic mutations. Inactivation of p53 allows tumor cells to circumvent normal cellular growth controls. Replication-deficient adenoviral viral vectors deliver p53 into glioma cells to inhibit tumor growth and trigger apoptosis [Vecil et al., 2003].

In phase one trials, patients were implanted with catheters to deliver Ad-p53 into their tumor mass. Several days after virus injection, tumors were resected to evaluate the extent of Ad-p53 biological effects. After resection further Ad-p53 was injected into the tumor cavity to determine toxicity [Lang et al., 2003].

Resected tumors showed p53 transduction however transduced cells were found no farther than $5-8 \mathrm{~mm}$ from the injection site. Evidence of apoptosis was restricted to a small number of cells. While no active virus outside of the CNS was detected, there were increased anti-adenoviral antibody titers. Some patients developed neurological side effects which responded to corticosteroid treatment. Survival to recurrence was a median of seven months [Lang et al., 2003].

\section{Oncolytic Viruses}

While concerns about toxicity to normal tissue with the use of replicating viral vectors have limited their study in humans, the decrease in therapeutic efficiency seen with replicationdeficient vectors as studies transition from pre-clinical to clinical has caused a resurgence in the study of the use of oncolytic or replicating viral vectors. Since widespread distribution of gene therapy products is essential for therapeutic efficacy, development of vectors which promote targeted but high level transduction efficiency are desired. Oncolytic virus infection results in viral replication and cell lysis such that no therapeutic transgene is need as the virus infection itself destroys the tumor mass. Herpes simplex virus, adenovirus, influenza virus, vaccinia virus, vesicular stomatitis virus, Newcastle disease virus, poliovirus, and reovirus are all being investigated for clinical oncolytic virus therapeutics, meanwhile adenovirus and herpes simplex virus have already entered clinical trials[Shah et al., 2003]. 
a. Adenovirus-While injection of wild-type virus may be detrimental to normal tissue, selective targeting by mutation of the virus has allowed for more selective killing of tumor cells. Mutated viruses are used to act directly as cytotoxic agents to destroy tumor cells and further spread newly replicated viral particles [Vecil et al., 2003].

ONYX-15: Among the adenoviruses, ONYX-15 has been used in clinical trials of glioma. The E1b region of wild-type adenovirus inactivates host cell p53 preventing apoptosis induction and allowing for viral replication. Originally, mutations in the E1b region of ONYX-15 were thought to render it unable to replicate in cells with normal p53 function [Shah et al., 2003]. While thought to only to kill cells exhibiting p53 mutations which result in deficits in p53 function, the mechanism by which ONYX-15 induces cell death is under intense investigation [Edwards et al., 2002; Petit et al., 2002; Hann et al., 2003; O'Shea et al., 2004]. In phase one clinical trials to examine toxicity and MTD in resected glioma patents, a maximum dose was not identified with up to $1 \times 10^{10}$ pfu being well tolerated [Chiocca et al., 2004]. No systemic toxicity was observed even with elevated levels of anti-adenoviral antibodies in several patients. While median survival was 6.2 months from recurrence several patients survived over a year. Development of other oncolytic adenoviruses in addition to ONYX-15 are underway [Fueyo et al., 2003].

b. Herpes Simplex Virus-HSV vectors have also been used as replication competent vectors to treat brain tumors. HSV is a non integrating, neurotropic virus with oncolytic properties that may be exploited in targeting brain tumors.

G207: HSV-G207 vectors contain two mutations separating them from wild-type HSV. The HSV $\gamma 134.5$ gene blocks activation of anti-viral defenses within a cell allowing viral protein synthesis to occur. $\gamma 134.5$ vectors only infect and replicate in cells without normal protein synthesis controls [He et al., 1997]. The second gene mutated in G207 is UL39 which is required to synthesize nucleotides in nondividing cells [Mineta et al., 1994; Mineta et al., 1995]. Disabling UL39 with a lacZ insertion disables nucleotide synthesis such that viral replication can only be carried out in actively dividing cells. While the two mutations within the virus confer specificity to G207, intact thymidine kinase gene provides a mechanism to control any herpetic infection that may arise from use of these replicating vectors.

In phase one clinical trials with G207, MTD and toxicity were evaluated [Markert et al., 2000]. Patents with progressive or recurrent glioma were injected with a single dose of virus. MTD was not established as the highest level $3 \times 10^{9}$ pfu was well tolerated. No herpetic, encephalic or inflammatory effects were observed. While one patient seroconverted showing positive anti-HSV1 antibodies after treatment, no systemic toxicity attributable to G207 treatment was observed. Excluding four surviving patients, mean survival from diagnosis to death was 15.9 months. Phase $1 \mathrm{~b} / 2$ trials are underway.

HSV1716: HSV1716 contains a single mutation of the y134.5 gene rendering it unable to replicate in neurons while targeting glioma cells. Phase one clinical trials in brain tumor patients were unable to determine a MTD as up to $1 \times 10^{5}$ pfu were tolerated well [Rampling et al., 2000]. No encephalitis or herpetic complications were observed and all patients remained seronegative for HSV-1. In an additional trial, recurrent tumor patient tumors were examined after injection of HSV1716 and virus was detectible by semiquantitative PCR [Papanastassiou et al., 2002]. Even in inoculated tumors for which virus was not detectible, reinfection in vitro triggered low level HSV1716 viral shedding indicating persistent long-term effects may be possible [Harland et al., 2002]. Following trials in which HSV1716 was injected intratumorally, HSV1716 was injected after resection into the rim of the tumor cavity to determine if virus administration could act to eliminate residual tumor cells responsible for rapid tumor regrowth after resection [Harrow et al., 2004]. No treatment related toxcicities 
were observed. Of twelve patients, 3 survived, one died of non related events, and 8 died after tumor progression. Further clinical trials are ongoing.

c. Newcastle Disease Virus-NDV replication-competent viruses have also been used in clinical trials to attempt treatment of GBM. Preclinically these viruses showed promising tumor regression without recurrence[Lorence et al., 1994; Phuangsab et al., 2001]. In a nonrandomized study of glioma patients, tumor cells taken from patients were infected with NDV, irradiated and used to vaccinate the patient. Vaccinated patients survived significantly longer than non-vaccinated controls and the therapy was well tolerated [Schneider et al., 2001; Steiner et al., 2004].

With promising results from replication competent adeno- and Newcastle disease virus interest in replication competent viruses continues to grow. Preclinical studies indicate the replicationcompetent retroviral vectors infect and selectively destroy glioma cells while sparing normal brain tissue[Wang et al., 2003]. These vectors could also be translated into phase I clinical trials.

\section{E. CONCLUSION AND FUTURE PROSPECTS}

The treatment of tumors of the central nervous system represents a formidable challenge, further magnified by the fact that the brain is isolated by the blood brain barrier which makes the delivery of high doses of chemotherapeutic agents or gene delivery vectors to the tumor very difficult. This posses the challenge of unacceptable toxic systemic levels of the drugs or vectors [Burton et al., 1999; Burton et al., 2000]. The approaches which propose combinations of local tumor delivery such as immune-stimulation and cytotoxic gene therapies within the tumor mass and/or surrounding tumor cavity are very promising for the effective treatment of GBM. Also, with the introduction of new technologies such as the microchip and convection enhanced drug delivery, it will be possible to achieve local delivery of high doses of the vectors carrying the therapeutic genes, both within the tumor mass and the surrounding area, where the infiltrating tumor cells are localized. These technologies should enable a more effective and constant delivery of the therapies, such as drugs or gene therapy vectors.

Taking gene therapies for GBM and other types of brain cancers to the clinic constitutes a very exciting prospect. One would envisage that when a patient undergoes surgical resection or debulking of the tumor, the neurosurgeon could deliver the gene therapy vectors encoding for a combination of therapeutic genes. By delivering genes which will enhance tumor cells' death and cytokines/chemokines which will elicit a systemic anti-tumor immune response, it will be possible to further eliminate tumor cells which have escaped the neurosurgical resection and also mount an effective anti-tumor immune response. The power of this approach is that the local antigen presenting cells (APCs) will be exposed to tumor antigens in situ as opposed to ex vivo. This will have the added advantage that the APCs will be loaded with the antigens released from the tumor in situ and will have more chance to mount an effective immune response when compared to loading of APCs with tumor extracts ex vivo. This is due to the fact that what kills the patients are the tumor recurrences and the tumor that recurs is very different from the primary tumor which was resected and used to load APCs ex vivo. Using gene delivery vectors with the capability of expressing therapeutic genes long term [Thomas et al., 2000; Thomas et al., 2001] and under the control of regulatable promoter systems [Goverdhana et al., 2005], one would eliminate the need of re-delivery of the gene therapies and also, by following the progression of the tumor by MRI or PET techniques, the neurooncologist will be able to make an informed decision as to whether the gene therapies will need to be turned on or reactivated for each individual patient. While these exciting prospects for GBM treatment will become a reality in the near future, more work is needed to perfect the gene delivery techniques and also in the development of powerful therapeutic targets. Results 
from the approaches described in this review will become available after phase I and II gene therapy trials are completed.

\section{ACKNOWLEDGEMENTS}

Gene therapy projects for neurological diseases are funded by; and the National Institutes of Health, National Institute of Neurological Disorders \& Stroke Grant 1R01 NS44556.01, National Institute of Diabetes and Digestive and Kidney Diseases 1 RO3 TW006273-01 to M.G.C.; National Institutes of Health, National Institute of Neurological Disorders \& Stroke Grant 1 RO1 NS 42893.01, U54 NS045309-01, and 1R21 NS047298-01 and Bram and Elaine Goldsmith Chair In Gene Therapeutics to P.R.L.; and The Linda Tallen \& David Paul Kane Annual Fellowship to M.G.C and P.R.L. G.D.K is funded by a NIH postdoctoral NRSA fellowship F32NS053034-01. We also thank the generous funding our Institute receives from the Board of Governors at Cedars Sinai Medical Center. We thank the academic leadership of Dr S. Melmed, and R. Katzman, and D. Meyer for their support.

\section{REFERENCES}

Abramovitch R, Meir G, Neeman M. Neovascularization induced growth of implanted C6 glioma multicellular spheroids: magnetic resonance microimaging. Cancer Res 1995;55(9):1956-62. [PubMed: 7537176]

Aghi M, Hochberg F, Breakefield XO. Prodrug activation enzymes in cancer gene therapy. J. Gene. Med 2000;2(3):148-64. [PubMed: 10894261]

Aghi M, Kramm CM, Chou TC, Breakefield XO, Chiocca EA. Synergistic anticancer effects of ganciclovir/thymidine kinase and 5-fluorocytosine/cytosine deaminase gene therapies. J. Natl. Cancer Inst 1998;90(5):370-80. [PubMed: 9498487]

Akbasak A, Oldfield EH, Saris SC. Expression and modulation of major histocompatibility antigens on murine primary brain tumor in vitro. J. Neurosurg 1991;75(6):922-9. [PubMed: 1941122]

Albright L, Madigan JC, Gaston MR, Houchens DP. Therapy in an intracerebral murine glioma model, using Bacillus Calmette-Guerin, neuraminidase-treated tumor cells, and 1-(2-chloroethyl)-3cyclohexyl-1-nitrosourea. Cancer Res 1975;35(3):658-65. [PubMed: 234790]

Ali S, Curtin JF, Zirger JM, Xiong W, King GD, Barcia C, Liu C, Puntel M, Goverdhana S, Lowenstein PR, Castro MG. Inflammatory and anti-glioma effects of an adenovirus expressing human soluble Fms-like tyrosine kinase 3 ligand. (hsFlt3L): treatment with hsFlt3L inhibits intracranial glioma progression. Mol. Ther 2004;10(6):1071-84. [PubMed: 15564139]

Ali S, King GD, Curtin JF, Candolfi M, Xiong W, Liu C, Puntel M, Cheng Q, Prieto J, Ribas A, KupiecWiglinski J, van Rooijen N, Lassmann H, Lowenstein PR, Castro MG. Combined immune stimulation and conditional cytotoxic gene therapy provide long-term survival in a large glioma model. Cancer Research 2005;65(16):7194-7204. [PubMed: 16103070]

Asai A, Miyagi Y, Sugiyama A, Gamanuma M, Hong SH, Takamoto S, Nomura K, Matsutani M, Takakura K, Kuchino Y. Negative effects of wild-type p53 and s-Myc on cellular growth and tumorigenicity of glioma cells. Implication of the tumor suppressor genes for gene therapy. J. Neurooncol 1994;19(3):259-68. [PubMed: 7807177]

Badie B, Drazan KE, Kramar MH, Shaked A, Black KL. Adenovirus-mediated p53 gene delivery inhibits 9L glioma growth in rats. Neurol. Res 1995;17(3):209-16. [PubMed: 7643977]

Badie B, Kramar MH, Lau R, Boothman DA, Economou JS, Black KL. Adenovirus-mediated p53 gene delivery potentiates the radiation-induced growth inhibition of experimental brain tumors. J. Neurooncol 1998;37(3):217-22. [PubMed: 9524079]

Barth RF. Rat brain tumor models in experimental neurooncology: the 9L, C6, T9, F98, RG2. (D74), RT-2 and CNS-1 gliomas. J. Neurooncol 1998;36(1):91-102. [PubMed: 9525831]

Beauchesne P. Promising survival and concomitant radiation plus temozolomide followed by adjuvant temozolomide. J. Clin. Oncol 2002;20(14):3180-1. [PubMed: 12118035] author reply 3181

Begemann M, Fuller GN, Holland EC. Genetic modeling of glioma formation in mice. Brain Pathol 2002;12(1):117-32. [PubMed: 11770894]

Benedetti S, Dimeco F, Pollo B, Cirenei N, Colombo BM, Bruzzone MG, Cattaneo E, Vescovi A, Didonato S, Colombo MP, Finocchiaro G. Limited efficacy of the HSV-TK/GCV system for gene therapy of malignant gliomas and perspectives for the combined transduction of the interleukin-4 gene. Hum. Gene. Ther 1997;8(11):1345-53. [PubMed: 9295129] 
Bi W, Kim YG, Feliciano ES, Pavelic L, Wilson KM, Pavelic ZP, Stambrook PJ. An HSVtk-mediated local and distant antitumor bystander effect in tumors of head and neck origin in athymic mice. Cancer Gene. Ther 1997;4(4):246-52. [PubMed: 9253510]

Biglari A, Bataille D, Naumann U, Weller M, Zirger J, Castro MG, Lowenstein PR. Effects of ectopic decorin in modulating intracranial glioma progression in vivo, in a rat syngeneic model. Cancer Gene. Ther 2004;11(11):721-32. [PubMed: 15475879]

Bischoff JR, Kirn DH, Williams A, Heise C, Horn S, Muna M, Ng L, Nye JA, Sampson-Johannes A, Fattaey A, McCormick F. An adenovirus mutant that replicates selectively in p53-deficient human tumor cells. Science 1996;274(5286):373-6. [PubMed: 8832876]

Boviatsis EJ, Park JS, Sena-Esteves M, Kramm CM, Chase M, Efird JT, Wei MX, Breakefield XO, Chiocca EA. Long-term survival of rats harboring brain neoplasms treated with ganciclovir and a herpes simplex virus vector that retains an intact thymidine kinase gene. Cancer Res 1994;54(22): 5745-51. [PubMed: 7954393]

Boviatsis EJ, Scharf JM, Chase M, Harrington K, Kowall NW, Breakefield XO, Chiocca EA. Antitumor activity and reporter gene transfer into rat brain neoplasms inoculated with herpes simplex virus vectors defective in thymidine kinase or ribonucleotide reductase. Gene. Ther 1994;1(5):323-31. [PubMed: 7584098]

Burton E, Prados M. New chemotherapy options for the treatment of malignant gliomas. Curr. Opin. Oncol 1999;11(3):157-61. [PubMed: 10328588]

Burton EC, Prados MD. Malignant gliomas. Curr. Treat Options Oncol 2000;1(5):459-68. [PubMed: 12057153]

Caruso M, Panis Y, Gagandeep S, Houssin D, Salzmann JL, Klatzmann D. Regression of established macroscopic liver metastases after in situ transduction of a suicide gene. Proc. Natl. Acad. Sci. USA 1993;90(15):7024-8. [PubMed: 8346212]

Castro MG, Cowen R, Williamson IK, David A, Jimenez-Dalmaroni MJ, Yuan X, Bigliari A, Williams JC, Hu J, Lowenstein PR. Current and future strategies for the treatment of malignant brain tumors. Pharmacol. Ther 2003;98(1):71-108. [PubMed: 12667889]

Chang JW, Lee H, Kim E, Lee Y, Chung SS, Kim JH. Combined antitumor effects of an adenoviral cytosine deaminase/thymidine kinase fusion gene in rat C6 glioma. Neurosurgery 2000;47(4):9318. [PubMed: 11014433]discussion 938-9

Chang TK, Weber GF, Crespi CL, Waxman DJ. Differential activation of cyclophosphamide and ifosphamide by cytochromes P-450 2B and 3A in human liver microsomes. Cancer Res 1993;53(23): 5629-37. [PubMed: 8242617]

Chen CY, Chang YN, Ryan P, Linscott M, McGarrity GJ, Chiang YL. Effect of herpes simplex virus thymidine kinase expression levels on ganciclovir-mediated cytotoxicity and the bystander effect. Hum. Gene. Ther 1995;6(11):1467-76. [PubMed: 8573619]

Chen J, Willingham T, Shuford M, Bruce D, Rushing E, Smith Y, Nisen PD. Effects of ectopic overexpression of $\mathrm{p} 21$ (WAF1/CIP1) on aneuploidy and the malignant phenotype of human brain tumor cells. Oncogene 1996;13(7):1395-403. [PubMed: 8875977]

Chen L, Waxman DJ. Intratumoral activation and enhanced chemotherapeutic effect of oxazaphosphorines following cytochrome P-450 gene transfer: development of a combined chemotherapy/cancer gene therapy strategy. Cancer Res 1995;55(3):581-9. [PubMed: 7834628]

Chen QR, Zhang L, Gasper W, Mixson AJ. Targeting tumor angiogenesis with gene therapy. Mol. Genet Metab 2001;74(12):120-7. [PubMed: 11592809]

Chen SH, Shine HD, Goodman JC, Grossman RG, Woo SL. Gene therapy for brain tumors: regression of experimental gliomas by adenovirus-mediated gene transfer in vivo. Proc. Natl. Acad. Sci. USA 1994;91(8):3054-7. [PubMed: 8159705]

Chiocca EA, Abbed KM, Tatter S, Louis DN, Hochberg FH, Barker F, Kracher J, Grossman SA, Fisher JD, Carson K, Rosenblum M, Mikkelsen T, Olson J, Markert J, Rosenfeld S, Nabors LB, Brem S, Phuphanich S, Freeman S, Kaplan R, Zwiebel J. A phase I open-label, dose-escalation, multiinstitutional trial of injection with an E1B-Attenuated adenovirus, ONYX-015, into the peritumoral region of recurrent malignant gliomas, in the adjuvant setting. Mol. Ther 2004;10(5):958-66. [PubMed: 15509513] 
Cirielli C, Inyaku K, Capogrossi MC, Yuan X, Williams JA. Adenovirus-mediated wild-type p53 expression induces apoptosis and suppresses tumorigenesis of experimental intracranial human malignant glioma. J. Neurooncol 1999;43(2):99-108. [PubMed: 10533721]

Cobb LM, Connors TA, Elson LA, Khan AH, Mitchley BC, Ross WC, Whisson ME. 2,4-dinitro-5ethyleneiminobenzamide. (CB 1954): a potent and selective inhibitor of the growth of the Walker carcinoma 256. Biochem. Pharmacol 1969;18(6):1519-27. [PubMed: 4307990]

Colombo F, Zanusso M, Casentini L, Cavaggioni A, Franchin E, Calvi P, Palu G. Gene stereotactic neurosurgery for recurrent malignant gliomas. Stereotact. Funct. Neurosurg 1997;68(14 Pt 1):24551. [PubMed: 9711724]

Connors TA, Whisson ME. Cure of mice bearing advanced plasma cell tumours with aniline mustard: the relationship between glucuronidase activity and tumour sensitivity. Nature 1966;210(38):866-7. [PubMed: 5958471]

Conrad C, Miller CR, Ji Y, Gomez-Manzano C, Bharara S, McMurray JS, Lang FF, Wong F, Sawaya R, Yung WK, Fueyo J. Delta24-hyCD adenovirus suppresses glioma growth in vivo by combining oncolysis and chemosensitization. Cancer Gene Ther 2005;12(3):284-94. [PubMed: 15650766]

Cowen RL, Williams JC, Emery S, Blakey D, Darling JL, Lowenstein PR, Castro MG. Adenovirus vectormediated delivery of the prodrug-converting enzyme carboxypeptidase G2 in a secreted or GPIanchored form: High-level expression of this active conditional cytotoxic enzyme at the plasma membrane. Cancer Gene Ther 2002;9(11):897-907. [PubMed: 12386828]

Cowsill C, Southgate TD, Morrissey G, Dewey RA, Morelli AE, Maleniak TC, Forrest Z, Klatzmann D, Wilkinson GW, Lowenstein PR, Castro MG. Central nervous system toxicity of two adenoviral vectors encoding variants of the herpes simplex virus type 1 thymidine kinase: reduced cytotoxicity of a truncated HSV1-TK. Gene. Ther 2000;7(8):679-85. [PubMed: 10800091]

Dachs GU, Tupper J, Tozer GM. From bench to bedside for gene-directed enzyme prodrug therapy of cancer. Anticancer Drugs 2005;16(4):349-59. [PubMed: 15746571]

Dai C, Celestino JC, Okada Y, Louis DN, Fuller GN, Holland EC. PDGF autocrine stimulation dedifferentiates cultured astrocytes and induces oligodendrogliomas and oligoastrocytomas from neural progenitors and astrocytes in vivo. Genes Dev 2001;15(15):1913-25. [PubMed: 11485986]

Darnell RB, DeAngelis LM. Regression of small-cell lung carcinoma in patients with paraneoplastic neuronal antibodies. Lancet 1993;341(8836):21-2. [PubMed: 8093269]

Debinski W, Gibo DM. Molecular expression analysis of restrictive receptor for interleukin 13, a brain tumor-associated cancer/testis antigen. Mol. Med 2000;6(5):440-9. [PubMed: 10952023]

Debinski W, Gibo DM, Hulet SW, Connor JR, Gillespie GY. Receptor for interleukin 13 is a marker and therapeutic target for human high-grade gliomas. Clin. Cancer Res 1999;5(5):985-90. [PubMed: 10353730]

Debinski W, Gibo DM, Obiri NI, Kealiher A, Puri RK. Novel anti-brain tumor cytotoxins specific for cancer cells. Nat. Biotechnol 1998;16(5):449-53. [PubMed: 9592393]

Debinski W, Miner R, Leland P, Obiri NI, Puri RK. Receptor for interleukin. (IL) 13 does not interact with IL4 but receptor for IL4 interacts with IL13 on human glioma cells. J. Biol. Chem 1996;271 (37):22428-33. [PubMed: 8798406]

Debinski W, Obiri NI, Pastan I, Puri RK. A novel chimeric protein composed of interleukin 13 and Pseudomonas exotoxin is highly cytotoxic to human carcinoma cells expressing receptors for interleukin 13 and interleukin 4. J. Biol. Chem 1995;270(28):16775-80. [PubMed: 7622490]

Debinski W, Obiri NI, Powers SK, Pastan I, Puri RK. Human glioma cells overexpress receptors for interleukin 13 and are extremely sensitive to a novel chimeric protein composed of interleukin 13 and pseudomonas exotoxin. Clin. Cancer Res 1995;1(11):1253-8. [PubMed: 9815919]

Debinski W, Pastan I. An immunotoxin with increased activity and homogeneity produced by reducing the number of lysine residues in recombinant Pseudomonas exotoxin. Bioconjug. Chem 1994;5(1): 40-6. [PubMed: 8199233]

Debinski W, Slagle B, Gibo DM, Powers SK, Gillespie GY. Expression of a restrictive receptor for interleukin 13 is associated with glial transformation. J. Neurooncol 2000;48(2):103-11. [PubMed: 11083073]

Dewey RA, Morrissey G, Cowsill CM, Stone D, Bolognani F, Dodd NJ, Southgate TD, Klatzmann D, Lassmann H, Castro MG, Lowenstein PR. Chronic brain inflammation and persistent herpes simplex 
virus 1 thymidine kinase expression in survivors of syngeneic glioma treated by adenovirus-mediated gene therapy: implications for clinical trials. Nat. Med 1999;5(11):1256-63. [PubMed: 10545991]

Dilber MS, Abedi MR, Bjorkstrand B, Christensson B, Gahrton G, Xanthopoulos KG, Smith CI. Suicide gene therapy for plasma cell tumors. Blood 1996;88(6):2192-200. [PubMed: 8822939]

Dilber MS, Abedi MR, Christensson B, Bjorkstrand B, Kidder GM, Naus CC, Gahrton G, Smith CI. Gap junctions promote the bystander effect of herpes simplex virus thymidine kinase in vivo. Cancer Res 1997;57(8):1523-8. [PubMed: 9108455]

Ding H, Roncari L, Shannon P, Wu X, Lau N, Karaskova J, Gutmann DH, Squire JA, Nagy A, Guha A. Astrocyte-specific expression of activated p21-ras results in malignant astrocytoma formation in a transgenic mouse model of human gliomas. Cancer Res 2001;61(9):3826-36. [PubMed: 11325859]

Domin BA, Mahony WB, Zimmerman TP. Transport of 5-fluorouracil and uracil into human erythrocytes. Biochem. Pharmacol 1993;46(3):503-10. [PubMed: 8347174]

Dorigo O, Turla ST, Lebedeva S, Gjerset RA. Sensitization of rat glioblastoma multiforme to cisplatin in vivo following restoration of wild-type p53 function. J. Neurosurg 1998;88(3):535-40. [PubMed: 9488309]

Edwards SJ, Dix BR, Myers CJ, Dobson-Le D, Huschtscha L, Hibma M, Royds J, Braithwaite AW. Evidence that replication of the antitumor adenovirus ONYX-015 is not controlled by the p53 and p14(ARF) tumor suppressor genes. J. Virol 2002;76(24):12483-90. [PubMed: 12438574]

Elshami AA, Saavedra A, Zhang H, Kucharczuk JC, Spray DC, Fishman GI, Amin KM, Kaiser LR, Albelda SM. Gap junctions play a role in the 'bystander effect' of the herpes simplex virus thymidine kinase/ganciclovir system in vitro. Gene. Ther 1996;3(1):85-92. [PubMed: 8929915]

Fischer HG, Bonifas U, Reichmann G. Phenotype and functions of brain dendritic cells emerging during chronic infection of mice with Toxoplasma gondii. J. Immunol 2000;164(9):4826-34. [PubMed: 10779791]

Fischer HG, Reichmann G. Brain dendritic cells and macrophages/microglia in central nervous system inflammation. J. Immunol 2001;166(4):2717-26. [PubMed: 11160337]

Fischer U, Steffens S, Frank S, Rainov NG, Schulze-Osthoff K, Kramm CM. Mechanisms of thymidine kinase/ganciclovir and cytosine deaminase/ 5-fluorocytosine suicide gene therapy-induced cell death in glioma cells. Oncogene 2005;24(7):1231-43. [PubMed: 15592511]

Floeth FW, Shand N, Bojar H, Prisack HB, Felsberg J, Neuen-Jacob E, Aulich A, Burger KJ, Bock WJ, Weber F. Local inflammation and devascularization--in vivo mechanisms of the bystander effect in VPC-mediated HSV-Tk/GCV gene therapy for human malignant glioma. Cancer Gene Ther 2001;8 (11):843-51. [PubMed: 11773974]

Frank S, Steffens S, Fischer U, Tlolko A, Rainov NG, Kramm CM. Differential cytotoxicity and bystander effect of the rabbit cytochrome P450 4B1 enzyme gene by two different prodrugs: implications for pharmacogene therapy. Cancer Gene Ther 2002;9(2):178-88. [PubMed: 11857036]

Freeman SM, Abboud CN, Whartenby KA, Packman CH, Koeplin DS, Moolten FL, Abraham GN. The bystander effect: tumor regression when a fraction of the tumor mass is genetically modified. Cancer Res 1993;53(21):5274-83. [PubMed: 8221662]

Freije WA, Castro-Vargas FE, Fang Z, Horvath S, Cloughesy T, Liau LM, Mischel PS, Nelson SF. Gene expression profiling of gliomas strongly predicts survival. Cancer Res 2004;64(18):6503-10. [PubMed: 15374961]

Fueyo J, Alemany R, Gomez-Manzano C, Fuller GN, Khan A, Conrad CA, Liu TJ, Jiang H, Lemoine MG, Suzuki K, Sawaya R, Curiel DT, Yung WK, Lang FF. Preclinical characterization of the antiglioma activity of a tropism-enhanced adenovirus targeted to the retinoblastoma pathway. J. Natl. Cancer Inst 2003;95(9):652-60. [PubMed: 12734316]

Fueyo J, Gomez-Manzano C, Alemany R, Lee PS, McDonnell TJ, Mitlianga P, Shi YX, Levin VA, Yung WK, Kyritsis AP. A mutant oncolytic adenovirus targeting the Rb pathway produces anti-glioma effect in vivo. Oncogene 2000;19(1):2-12. [PubMed: 10644974]

Fueyo J, Gomez-Manzano C, Yung WK, Liu TJ, Alemany R, McDonnell TJ, Shi X, Rao JS, Levin VA, Kyritsis AP. Overexpression of E2F-1 in glioma triggers apoptosis and suppresses tumor growth in vitro and in vivo. Nat. Med 1998;4(6):685-90. [PubMed: 9623977] 
Gadi VK, Alexander SD, Waud WR, Allan PW, Parker WB, Sorscher EJ. A long-acting suicide gene toxin, 6-methylpurine, inhibits slow growing tumors after a single administration. J. Pharmacol. Exp. Ther 2003;304(3):1280-4. [PubMed: 12604707]

Galli R, Binda E, Orfanelli U, Cipelletti B, Gritti A, De Vitis S, Fiocco R, Foroni C, Dimeco F, Vescovi A. Isolation and characterization of tumorigenic, stem-like neural precursors from human glioblastoma. Cancer Res 2004;64(19):7011-21. [PubMed: 15466194]

Ge K, Xu L, Zheng Z, Xu D, Sun L, Liu X. Transduction of cytosine deaminase gene makes rat glioma cells highly sensitive to 5-fluorocytosine. Int. J. Cancer 1997;71(4):675-9. [PubMed: 9178825]

Geoerger B, Grill J, Opolon P, Morizet J, Aubert G, Lecluse Y, van Beusechem VW, Gerritsen WR, Kirn DH, Vassal G. Potentiation of radiation therapy by the oncolytic adenovirus d11520. (ONYX-015) in human malignant glioma xenografts. Br. J. Cancer 2003;89(3):577-84. [PubMed: 12888833]

Germano IM, Fable J, Gultekin SH, Silvers A. Adenovirus/herpes simplex-thymidine kinase/ganciclovir complex: preliminary results of a phase I trial in patients with recurrent malignant gliomas. J. Neurooncol 2003;65(3):279-89. [PubMed: 14682378]

Gjerset RA, Turla ST, Sobol RE, Scalise JJ, Mercola D, Collins H, Hopkins PJ. Use of wild-type p53 to achieve complete treatment sensitization of tumor cells expressing endogenous mutant p53. Mol. Carcinog 1995;14(4):275-85. [PubMed: 8519417]

Gondi CS, Lakka SS, Dinh DH, Olivero WC, Gujrati M, Rao JS. RNAi-mediated inhibition of cathepsin $\mathrm{B}$ and $\mathrm{UPAR}$ leads to decreased cell invasion, angiogenesis and tumor growth in gliomas. Oncogene 2004;23(52):8486-96. [PubMed: 15378018]

Gondi CS, Lakka SS, Yanamandra N, Olivero WC, Dinh DH, Gujrati M, Tung CH, Weissleder R, Rao JS. Adenovirus-mediated expression of antisense urokinase plasminogen activator receptor and antisense cathepsin B inhibits tumor growth, invasion, and angiogenesis in gliomas. Cancer Res 2004;64(12):4069-77. [PubMed: 15205313]

Goverdhana S, Puntel M, Xiong W, Zirger J, Barcia C, Curtin JF, Soffer EB, Mondakar S, King GD, Hu J, Sciascia SA, Candolfi M, Lowenstein P, Castro MG. Regulatable gene expression systems for gene therapy applications:progress and future challenges. Mol. Ther. 2005in press

Greco O, Dachs GU. Gene directed enzyme/prodrug therapy of cancer: historical appraisal and future prospectives. J. Cell Physiol 2001;187(1):22-36. [PubMed: 11241346]

Greenfield L, Johnson VG, Youle RJ. Mutations in diphtheria toxin separate binding from entry and amplify immunotoxin selectivity. Science 1987;238(4826):536-9. [PubMed: 3498987]

Hann B, Balmain A. Replication of an E1B 55-kilodalton protein-deficient adenovirus. (ONYX-015) is restored by gain-of-function rather than loss-of-function p53 mutants. J. Virol 2003;77(21):1158895. [PubMed: 14557644]

Harland J, Papanastassiou V, Brown SM. HSV1716 persistence in primary human glioma cells in vitro. Gene Ther 2002;9(17):1194-8. [PubMed: 12170384]

Harrow S, Papanastassiou V, Harland J, Mabbs R, Petty R, Fraser M, Hadley D, Patterson J, Brown SM, Rampling R. HSV1716 injection into the brain adjacent to tumour following surgical resection of high-grade glioma: safety data and long-term survival. Gene Ther 2004;11(22):1648-58. [PubMed: 15334111]

Harsh GR, Deisboeck TS, Louis DN, Hilton J, Colvin M, Silver JS, Qureshi NH, Kracher J, Finkelstein D, Chiocca EA, Hochberg FH. Thymidine kinase activation of ganciclovir in recurrent malignant gliomas: a gene-marking and neuropathological study. J. Neurosurg 2000;92(5):804-11. [PubMed: 10794295]

He B, Gross M, Roizman B. The gamma(1)34.5 protein of herpes simplex virus 1 complexes with protein phosphatase 1alpha to dephosphorylate the alpha subunit of the eukaryotic translation initiation factor 2 and preclude the shutoff of protein synthesis by double-stranded RNA-activated protein kinase. Proc. Natl. Acad. Sci. USA 1997;94(3):843-8. [PubMed: 9023344]

Heidenreich R, Machein M, Nicolaus A, Hilbig A, Wild C, Clauss M, Plate KH, Breier G. Inhibition of solid tumor growth by gene transfer of VEGF receptor-1 mutants. Int. J. Cancer 2004;111(3):34857. [PubMed: 15221961]

Heimberger AB, Crotty LE, Archer GE, McLendon RE, Friedman A, Dranoff G, Bigner DD, Sampson $\mathrm{JH}$. Bone marrow-derived dendritic cells pulsed with tumor homogenate induce immunity against syngeneic intracerebral glioma. J. Neuroimmunol 2000;103(1):16-25. [PubMed: 10674985] 
Heise C, Sampson-Johannes A, Williams A, McCormick F, Von Hoff DD, Kirn DH. ONYX-015, an E1B gene-attenuated adenovirus, causes tumor-specific cytolysis and antitumoral efficacy that can be augmented by standard chemotherapeutic agents. Nat. Med 1997;3(6):639-45. [PubMed: 9176490]

Hong JS, Waud WR, Levasseur DN, Townes TM, Wen H, McPherson SA, Moore BA, Bebok Z, Allan PW, Secrist JA 3rd, Parker WB, Sorscher EJ. Excellent in vivo bystander activity of fludarabine phosphate against human glioma xenografts that express the escherichia coli purine nucleoside phosphorylase gene. Cancer Res 2004;64(18):6610-5. [PubMed: 15374975]

Horton HM, Anderson D, Hernandez P, Barnhart KM, Norman JA, Parker SE. A gene therapy for cancer using intramuscular injection of plasmid DNA encoding interferon alpha. Proc. Natl. Acad. Sci. USA 1999;96(4):1553-8. [PubMed: 9990062]

Huang Z, Raychowdhury MK, Waxman DJ. Impact of liver P450 reductase suppression on cyclophosphamide activation, pharmacokinetics and antitumoral activity in a cytochrome P450based cancer gene therapy model. Cancer Gene Ther 2000;7(7):1034-42. [PubMed: 10917206]

Huber BE, Austin EA, Richards CA, Davis ST, Good SS. Metabolism of 5-fluorocytosine to 5fluorouracil in human colorectal tumor cells transduced with the cytosine deaminase gene: significant antitumor effects when only a small percentage of tumor cells express cytosine deaminase. Proc. Natl. Acad. Sci. USA 1994;91(17):8302-6. [PubMed: 8058798]

Husain SR, Joshi BH, Puri RK. Interleukin-13 receptor as a unique target for anti-glioblastoma therapy. Int. J. Cancer 2001;92(2):168-75. [PubMed: 11291041]

Ichikawa T, Tamiya T, Adachi Y, Ono Y, Matsumoto K, Furuta T, Yoshida Y, Hamada H, Ohmoto T. In vivo efficacy and toxicity of 5-fluorocytosine/cytosine deaminase gene therapy for malignant gliomas mediated by adenovirus. Cancer Gene Ther 2000;7(1):74-82. [PubMed: 10678359]

Immonen A, Vapalahti M, Tyynela K, Hurskainen H, Sandmair A, Vanninen R, Langford G, Murray N, Yla-Herttuala S. AdvHSV-tk gene therapy with intravenous ganciclovir improves survival in human malignant glioma: a randomised, controlled study. Mol. Ther 2004;10(5):967-72. [PubMed: 15509514]

Izquierdo M, Cortes M, de Felipe P, Martin V, Diez-Guerra J, Talavera A, Perez-Higueras A. Long-term rat survival after malignant brain tumor regression by retroviral gene therapy. Gene Ther 1995;2(1): 66-9. [PubMed: 7712334]

Izquierdo M, Cortes ML, Martin V, de Felipe P, Izquierdo JM, Perez-Higueras A, Paz JF, Isla A, Blazquez MG. Gene therapy in brain tumours: implications of the size of glioblastoma on its curability. Acta Neurochir. Suppl 1997;68:111-7. [PubMed: 9233425]

Izquierdo M, Martin V, de Felipe P, Izquierdo JM, Perez-Higueras A, Cortes ML, Paz JF, Isla A, Blazquez MG. Human malignant brain tumor response to herpes simplex thymidine kinase. (HSVtk)/ ganciclovir gene therapy. Gene Ther 1996;3(6):491-5. [PubMed: 8789798]

Johnson VG, Wrobel C, Wilson D, Zovickian J, Greenfield L, Oldfield EH, Youle R. Improved tumorspecific immunotoxins in the treatment of CNS and leptomeningeal neoplasia. J. Neurosurg 1989;70 (2):240-8. [PubMed: 2783608]

Jongmans W, van den Oudenalder K, Tiemessen DM, Molkenboer J, Willemsen R, Mulders PF, Oosterwijk E. Targeting of adenovirus to human renal cell carcinoma cells. Urology 2003;62(3):559_ 65. [PubMed: 12946777]

Jounaidi Y, Waxman DJ. Combination of the bioreductive drug tirapazamine with the chemotherapeutic prodrug cyclophosphamide for P450/P450-reductase-based cancer gene therapy. Cancer Res 2000;60 (14):3761-9. [PubMed: 10919648]

Kambara H, Tamiya T, Ono Y, Ohtsuka S, Terada K, Adachi Y, Ichikawa T, Hamada H, Ohmoto T. Combined radiation and gene therapy for brain tumors with adenovirus-mediated transfer of cytosine deaminase and uracil phosphoribosyltransferase genes. Cancer Gene. Ther 2002;9(10): 840-5. [PubMed: 12224025]

Kawakami K, Kawakami M, Kioi M, Husain SR, Puri RK. Distribution kinetics of targeted cytotoxin in glioma by bolus or convection-enhanced delivery in a murine model. J. Neurosurg 2004;101(6): 1004-11. [PubMed: 15597761] 
Kemp TJ, Elzey BD, Griffith TS. Plasmacytoid dendritic cell-derived IFN-alpha induces TNF-related apoptosis-inducing ligand/Apo-2L-mediated antitumor activity by human monocytes following CpG oligodeoxynucleotide stimulation. J. Immunol 2003;171(1):212-8. [PubMed: 12817000]

Kim SH, Kim JH, Kolozsvary A, Brown SL, Freytag SO. Preferential radiosensitization of 9L glioma cells transduced with HSV-tk gene by acyclovir. J. Neurooncol 1997;33(3):189-94. [PubMed: 9195489]

Kirsch M, Schackert G, Black PM. Anti-angiogenic treatment strategies for malignant brain tumors. J. Neurooncol 2000;50(12):149-63. [PubMed: 11245274]

Klatzmann D, Valery CA, Bensimon G, Marro B, Boyer O, Mokhtari K, Diquet B, Salzmann JL, Philippon J. A phase I/II study of herpes simplex virus type 1 thymidine kinase suicide gene therapy for recurrent glioblastoma. Study Group on Gene Therapy for Glioblastoma. Hum. Gene Ther 1998;9(17):2595-604. [PubMed: 9853526]

Kleihues P, Zulch KJ, Matsumoto S, Radke U. Morphology of malignant gliomas induced in rabbits by systemic application of N-methyl-N-nitrosourea. Z. Neurol 1970;198(1):65-78. [PubMed: 4100120]

Kock H, Harris MP, Anderson SC, Machemer T, Hancock W, Sutjipto S, Wills KN, Gregory RJ, Shepard HM, Westphal M, Maneval DC. Adenovirus-mediated p53 gene transfer suppresses growth of human glioblastoma cells in vitro and in vivo. Int. J. Cancer 1996;67(6):808-15. [PubMed: 8824552]

Kramm CM, Korholz D, Rainov NG, Niehues T, Fischer U, Steffens S, Frank S, Banning U, Horneff G, Schroten H, Burdach S. Systemic activation of the immune system during ganciclovir treatment following intratumoral herpes simplex virus type 1 thymidine kinase gene transfer in an adolescent ependymoma patient. Neuropediatrics 2002;33(1):6-9. [PubMed: 11930269]

Kruse CA, Molleston MC, Parks EP, Schiltz PM, Kleinschmidt-DeMasters BK, Hickey WF. A rat glioma model, CNS-1, with invasive characteristics similar to those of human gliomas: a comparison to 9L gliosarcoma. J. Neurooncol 1994;22(3):191-200. [PubMed: 7760095]

Kunwar S. Convection enhanced delivery of IL13-PE38QQR for treatment of recurrent malignant glioma: presentation of interim findings from ongoing phase 1 studies. Acta Neurochir. Suppl 2003;88:10511. [PubMed: 14531568]

Kurozumi K, Tamiya T, Ono Y, Otsuka S, Kambara H, Adachi Y, Ichikawa T, Hamada H, Ohmoto T. Apoptosis induction with 5-fluorocytosine/cytosine deaminase gene therapy for human malignant glioma cells mediated by adenovirus. J. Neurooncol 2004;66(12):117-27. [PubMed: 15015777]

Lampson LA. New animal models to probe brain tumor biology, therapy, and immunotherapy: advantages and remaining concerns. J. Neurooncol 2001;53(3):275-87. [PubMed: 11718260]

Lang FF, Bruner JM, Fuller GN, Aldape K, Prados MD, Chang S, Berger MS, McDermott MW, Kunwar SM, Junck LR, Chandler W, Zwiebel JA, Kaplan RS, Yung WK. Phase I trial of adenovirusmediated p53 gene therapy for recurrent glioma: biological and clinical results. J. Clin.. Oncol 2003;21(13):2508-18. [PubMed: 12839017]

Laouar Y, Crispe IN. Functional flexibility in T cells: independent regulation of CD4+ T cell proliferation and effector function in vivo. Immunity 2000;13(3):291-301. [PubMed: 11021527]

Laske DW, Youle RJ, Oldfield EH. Tumor regression with regional distribution of the targeted toxin TFCRM107 in patients with malignant brain tumors. Nat. Med 1997;3(12):1362-8. [PubMed: 9396606]

Lee SH, Kim MS, Kwon HC, Park IC, Park MJ, Lee CT, Kim YW, Kim CM, Hong SI. Growth inhibitory effect on glioma cells of adenovirus-mediated p16/INK4a gene transfer in vitro and in vivo. Int. J. Mol. Med 2000;6(5):559-63. [PubMed: 11029524]

Lefranc F, Brotchi J, Kiss R. Possible future issues in the treatment of glioblastomas: special emphasis on cell migration and the resistance of migrating glioblastoma cells to apoptosis. J. Clin.. Oncol 2005;23(10):2411-22. [PubMed: 15800333]

Li C, Hall WA, Jin N, Todhunter DA, Panoskaltsis-Mortari A, Vallera DA. Targeting glioblastoma multiforme with an IL-13/diphtheria toxin fusion protein in vitro and in vivo in nude mice. Protein Eng 2002;15(5):419-27. [PubMed: 12034862]

Li H, Alonso-Vanegas M, Colicos MA, Jung SS, Lochmuller H, Sadikot AF, Snipes GJ, Seth P, Karpati G, Nalbantoglu J. Intracerebral adenovirus-mediated p53 tumor suppressor gene therapy for experimental human glioma. Clin. Cancer Res 1999;5(3):637-42. [PubMed: 10100717] 
Lichtor T, Glick RP. Cytokine immuno-gene therapy for treatment of brain tumors. J. Neurooncol 2003;65 (3):247-59. [PubMed: 14682375]

Liu TF, Hall PD, Cohen KA, Willingham MC, Cai J, Thorburn A, Frankel AE. Interstitial diphtheria toxin-epidermal growth factor fusion protein therapy produces regressions of subcutaneous human glioblastoma multiforme tumors in athymic nude mice. Clin. Cancer Res 2005;11(1):329-34. [PubMed: 15671563]

Liu TF, Willingham MC, Tatter SB, Cohen KA, Lowe AC, Thorburn A, Frankel AE. Diphtheria toxinepidermal growth factor fusion protein and Pseudomonas exotoxin-interleukin 13 fusion protein exert synergistic toxicity against human glioblastoma multiforme cells. Bioconjug. Chem 2003;14 (6):1107-14. [PubMed: 14624623]

Liu Y, Ehtesham M, Samoto K, Wheeler CJ, Thompson RC, Villarreal LP, Black KL, Yu JS. In situ adenoviral interleukin 12 gene transfer confers potent and long-lasting cytotoxic immunity in glioma. Cancer Gene Ther 2002;9(1):9-15. [PubMed: 11916248]

Long Z, Li LP, Grooms T, Lockey C, Nader K, Mychkovsky I, Mueller S, Burimski I, Ryan P, Kikuchi G, Ennist D, Marcus S, Otto E, McGarrity G. Biosafety monitoring of patients receiving intracerebral injections of murine retroviral vector producer cells. Hum. Gene Ther 1998;9(8):116572. [PubMed: 9625255]

Long Z, Lu P, Grooms T, Mychkovsky I, Westley T, Fitzgerald T, Sharma-Chibber S, Shand N, McGarrity G, Otto E. Molecular evaluation of biopsy and autopsy specimens from patients receiving in vivo retroviral gene therapy. Hum. Gene Ther 1999;10(5):733-40. [PubMed: 10210141]

Lorence RM, Katubig BB, Reichard KW, Reyes HM, Phuangsab A, Sassetti MD, Walter RJ, Peeples ME. Complete regression of human fibrosarcoma xenografts after local Newcastle disease virus therapy. Cancer Res 1994;54(23):6017-21. [PubMed: 7954437]

Louis DN. The p53 gene and protein in human brain tumors. J. Neuropathol. Exp. Neurol 1994;53(1): 11-21. [PubMed: 8301315]

Lowenstein PR. Immunology of viral-vector-mediated gene transfer into the brain: an evolutionary and developmental perspective. Trends Immunol 2002;23(1):23-30. [PubMed: 11801451]

Lynch DH, Andreasen A, Maraskovsky E, Whitmore J, Miller RE, Schuh JC. Flt3 ligand induces tumor regression and antitumor immune responses in vivo. Nat. Med 1997;3(6):625-31. [PubMed: 9176488]

Ma HI, Lin SZ, Chiang YH, Li J, Chen SL, Tsao YP, Xiao X. Intratumoral gene therapy of malignant brain tumor in a rat model with angiostatin delivered by adeno-associated viral. (AAV) vector. Gene Ther 2002;9(1):2-11. [PubMed: 11850717]

Machein MR, Risau W, Plate KH. Antiangiogenic gene therapy in a rat glioma model using a dominantnegative vascular endothelial growth factor receptor 2. Hum. Gene Ther 1999;10(7):1117-28. [PubMed: 10340544]

Madhankumar AB, Mintz A, Debinski W. Interleukin 13 mutants of enhanced avidity toward the gliomaassociated receptor, IL13Ralpha2. Neoplasia 2004;6(1):15-22. [PubMed: 15068667]

Maher EA, Furnari FB, Bachoo RM, Rowitch DH, Louis DN, Cavenee WK, DePinho RA. Malignant glioma: genetics and biology of a grave matter. Genes Dev 2001;15(11):1311-33. [PubMed: 11390353]

Manome Y, Wen PY, Chen L, Tanaka T, Dong Y, Yamazoe M, Hirshowitz A, Kufe DW, Fine HA. Gene therapy for malignant gliomas using replication incompetent retroviral and adenoviral vectors encoding the cytochrome P450 2B1 gene together with cyclophosphamide. Gene Ther 1996;3(6): 513-20. [PubMed: 8789801]

Marais R, Spooner RA, Light Y, Martin J, Springer CJ. Gene-directed enzyme prodrug therapy with a mustard prodrug/carboxypeptidase G2 combination. Cancer Res 1996;56(20):4735-42. [PubMed: 8840992]

Marconi P, Tamura M, Moriuchi S, Krisky DM, Niranjan A, Goins WF, Cohen JB, Glorioso JC. Connexin 43-enhanced suicide gene therapy using herpesviral vectors. Mol. Ther 2000;1(1):71-81. [PubMed: 10933914]

Markert JM, Medlock MD, Rabkin SD, Gillespie GY, Todo T, Hunter WD, Palmer CA, Feigenbaum F, Tornatore C, Tufaro F, Martuza RL. Conditionally replicating herpes simplex virus mutant, G207 
for the treatment of malignant glioma: results of a phase I trial. Gene Ther 2000;7(10):867-74. [PubMed: 10845725]

McMenamin PG. Distribution and phenotype of dendritic cells and resident tissue macrophages in the dura mater, leptomeninges, and choroid plexus of the rat brain as demonstrated in wholemount preparations. J. Comp. Neurol 1999;405(4):553-62. [PubMed: 10098945]

Merlo A. Genes and pathways driving glioblastomas in humans and murine disease models. Neurosurg. Rev 2003;26(3):145-58. [PubMed: 12783270]

Mesnil M, Piccoli. Tiraby G, Willecke K, Yamasaki H. Bystander killing of cancer cells by herpes simplex virus thymidine kinase gene is mediated by connexins. Proc. Natl. Acad. Sci. USA 1996;93(5): 1831-5. [PubMed: 8700844]

Mineta T, Rabkin SD, Martuza RL. Treatment of malignant gliomas using ganciclovir-hypersensitive, ribonucleotide reductase-deficient herpes simplex viral mutant. Cancer Res 1994;54(15):3963-6. [PubMed: 8033122]

Mineta T, Rabkin SD, Yazaki T, Hunter WD, Martuza RL. Attenuated multi-mutated herpes simplex virus-1 for the treatment of malignant gliomas. Nat. Med 1995;1(9):938-43. [PubMed: 7585221]

Mintz A, Gibo DM, Madhankumar AB, Debinski W. Molecular targeting with recombinant cytotoxins of interleukin-13 receptor alpha2-expressing glioma. J. Neurooncol 2003;64(12):117-23. [PubMed: 12952292]

Mintz A, Gibo DM, Slagle-Webb B, Christensen ND, Debinski W. IL-13Ralpha2 is a glioma-restricted receptor for interleukin-13. Neoplasia 2002;4(5):388-99. [PubMed: 12192597]

Mizuno M, Yoshida J, Colosi P, Kurtzman G. Adeno-associated virus vector containing the herpes simplex virus thymidine kinase gene causes complete regression of intracerebrally implanted human gliomas in mice, in conjunction with ganciclovir administration. Jpn. J. Cancer Res 1998;89(1):7680. [PubMed: 9510479]

Montesano R, Vassalli JD, Baird A, Guillemin R, Orci L. Basic fibroblast growth factor induces angiogenesis in vitro. Proc. Natl. Acad. Sci. USA 1986;83(19):7297-301. [PubMed: 2429303]

Moolten FL. Tumor chemosensitivity conferred by inserted herpes thymidine kinase genes: paradigm for a prospective cancer control strategy. Cancer Res 1986;46(10):5276-81. [PubMed: 3019523]

Mori T, Abe T, Wakabayashi Y, Hikawa T, Matsuo K, Yamada Y, Kuwano M, Hori S. Up-regulation of urokinase-type plasminogen activator and its receptor correlates with enhanced invasion activity of human glioma cells mediated by transforming growth factor-alpha or basic fibroblast growth factor. J. Neurooncol 2000;46(2):115-23. [PubMed: 10894364]

Moriuchi S, Oligino T, Krisky D, Marconi P, Fink D, Cohen J, Glorioso JC. Enhanced tumor cell killing in the presence of ganciclovir by herpes simplex virus type 1 vector-directed coexpression of human tumor necrosis factor-alpha and herpes simplex virus thymidine kinase. Cancer Res 1998;58(24): 5731-7. [PubMed: 9865731]

Nagel GA, Piessens WF, Stilmant MM, Lejeune F. Evidence for tumor-specific immunity in human malignant melanoma. Eur. J. Cancer 1971;7(1):41-7. [PubMed: 5576728]

Nakahara N, Pollack IF, Storkus WJ, Wakabayashi T, Yoshida J, Okada H. Effective induction of antiglioma cytotoxic $\mathrm{T}$ cells by coadministration of interferon-beta gene vector and dendritic cells. Cancer Gene Ther 2003;10(7):549-58. [PubMed: 12833135]

Nanda D, Vogels R, Havenga M, Avezaat CJ, Bout A, Smitt PS. Treatment of malignant gliomas with a replicating adenoviral vector expressing herpes simplex virus-thymidine kinase. Cancer Res 2001;61(24):8743-50. [PubMed: 11751394]

Natsume A, Tsujimura K, Mizuno M, Takahashi T, Yoshida J. IFN-beta gene therapy induces systemic antitumor immunity against malignant glioma. J. Neurooncol 2000;47(2):117-24. [PubMed: 10982152]

Nestler U, Wakimoto H, Siller-Lopez F, Aguilar LK, Chakravarti A, Muzikansky A, StemmerRachamimov A, Chiocca EA, Aguilar-Cordova E, Hochberg FH. The combination of adenoviral HSV TK gene therapy and radiation is effective in athymic mouse glioblastoma xenografts without increasing toxic side effects. J. Neurooncol 2004;67(12):177-88. [PubMed: 15072465]

Niranjan A, Moriuchi S, Lunsford LD, Kondziolka D, Flickinger JC, Fellows W, Rajendiran S, Tamura M, Cohen JB, Glorioso JC. Effective treatment of experimental glioblastoma by HSV vector- 
mediated TNF alpha and HSV-tk gene transfer in combination with radiosurgery and ganciclovir administration. Mol. Ther 2000;2(2):114-20. [PubMed: 10947938]

Niranjan A, Wolfe D, Tamura M, Soares MK, Krisky DM, Lunsford LD, Li S, Fellows-Mayle W, DeLuca NA, Cohen JB, Glorioso JC. Treatment of rat gliosarcoma brain tumors by HSV-based multigene therapy combined with radiosurgery. Mol Ther 2003;8(4):530-42. [PubMed: 14529825]

O'Reilly MS, Boehm T, Shing Y, Fukai N, Vasios G, Lane WS, Flynn E, Birkhead JR, Olsen BR, Folkman J. Endostatin: an endogenous inhibitor of angiogenesis and tumor growth. Cell 1997;88(2):277-85. [PubMed: 9008168]

O'Reilly MS, Holmgren L, Shing Y, Chen C, Rosenthal RA, Moses M, Lane WS, Cao Y, Sage EH, Folkman J. Angiostatin: a novel angiogenesis inhibitor that mediates the suppression of metastases by a Lewis lung carcinoma. Cell 1994;79(2):315-28. [PubMed: 7525077]

O'Shea CC, Johnson L, Bagus B, Choi S, Nicholas C, Shen A, Boyle L, Pandey K, Soria C, Kunich J, Shen Y, Habets G, Ginzinger D, McCormick F. Late viral RNA export, rather than $\mathrm{p} 53$ inactivation, determines ONYX-015 tumor selectivity. Cancer Cell 2004;6(6):611-23. [PubMed: 15607965]

Okada H, Pollack IF, Lieberman F, Lunsford LD, Kondziolka D, Schiff D, Attanucci J, Edington H, Chambers W, Kalinski P, Kinzler D, Whiteside T, Elder E, Potter D. Gene therapy of malignant gliomas: a pilot study of vaccination with irradiated autologous glioma and dendritic cells admixed with IL-4 transduced fibroblasts to elicit an immune response. Hum. Gene Ther 2001;12(5):57595. [PubMed: 11268289]

Okada H, Pollack IF, Lotze MT, Lunsford LD, Kondziolka D, Lieberman F, Schiff D, Attanucci J, Edington H, Chambers W, Robbins P, Baar J, Kinzler D, Whiteside T, Elder E. Gene therapy of malignant gliomas: a phase I study of IL-4-HSV-TK gene-modified autologous tumor to elicit an immune response. Hum. Gene Ther 2000;11(4):637-53. [PubMed: 10724042]

Packer RJ, Raffel C, Villablanca JG, Tonn JC, Burdach SE, Burger K, LaFond D, McComb JG, Cogen $\mathrm{PH}$, Vezina G, Kapcala LP. Treatment of progressive or recurrent pediatric malignant supratentorial brain tumors with herpes simplex virus thymidine kinase gene vector-producer cells followed by intravenous ganciclovir administration. J. Neurosurg 2000;92(2):249-54. [PubMed: 10659011]

Palu G, Cavaggioni A, Calvi P, Franchin E, Pizzato M, Boschetto R, Parolin C, Chilosi M, Ferrini S, Zanusso A, Colombo F. Gene therapy of glioblastoma multiforme via combined expression of suicide and cytokine genes: a pilot study in humans. Gene Ther 1999;6(3):330-7. [PubMed: 10435083]

Papanastassiou V, Rampling R, Fraser M, Petty R, Hadley D, Nicoll J, Harland J, Mabbs R, Brown M. The potential for efficacy of the modified. (ICP 34.5(-)) herpes simplex virus HSV1716 following intratumoural injection into human malignant glioma: a proof of principle study. Gene Ther 2002;9 (6):398-406. [PubMed: 11960316]

Parker WB, Allan PW, Hassan AE, Secrist JA 3rd, Sorscher EJ, Waud WR. Antitumor activity of 2fluoro-2'-deoxyadenosine against tumors that express Escherichia coli purine nucleoside phosphorylase. Cancer Gene Ther 2003;10(1):23-9. [PubMed: 12489025]

Parker WB, King SA, Allan PW, Bennett LL Jr. Secrist JA 3rd, Montgomery JA, Gilbert KS, Waud WR, Wells AH, Gillespie GY, Sorscher EJ. In vivo gene therapy of cancer with E. coli purine nucleoside phosphorylase. Hum. Gene Ther 1997;8(14):1637-44. [PubMed: 9322865]

Pastan I, Chaudhary V, FitzGerald DJ. Recombinant toxins as novel therapeutic agents. Annu. Rev. Biochem 1992;61:331-54. [PubMed: 1497314]

Paul WE. Interleukin-4: a prototypic immunoregulatory lymphokine. Blood 1991;77(9):1859-70. [PubMed: 2018830]

Perez-Cruet MJ, Trask TW, Chen SH, Goodman JC, Woo SL, Grossman RG, Shine HD. Adenovirusmediated gene therapy of experimental gliomas. J. Neurosci. Res 1994;39(4):506-11. [PubMed: 7884826]

Peroulis I, Jonas N, Saleh M. Antiangiogenic activity of endostatin inhibits C6 glioma growth. Int. J. Cancer 2002;97(6):839-45. [PubMed: 11857365]

Petit T, Davidson KK, Cerna C, Lawrence RA, Von Hoff DD, Heise C, Kirn D, Izbicka E. Efficient induction of apoptosis by ONYX-015 adenovirus in human colon cancer cell lines regardless of p53 status. Anticancer Drugs 2002;13(1):47-50. [PubMed: 11914640] 
Phillips PC, Levow C, Catterall M, Colvin OM, Pastan I, Brem H. Transforming growth factor-alphaPseudomonas exotoxin fusion protein. (TGF-alpha-PE38) treatment of subcutaneous and intracranial human glioma and medulloblastoma xenografts in athymic mice. Cancer Res 1994;54 (4):1008-15. [PubMed: 8313355]

Phuangsab A, Lorence RM, Reichard KW, Peeples ME, Walter RJ. Newcastle disease virus therapy of human tumor xenografts: antitumor effects of local or systemic administration. Cancer Lett 2001;172(1):27-36. [PubMed: 11595126]

Plate KH, Risau W. Angiogenesis in malignant gliomas. Glia 1995;15(3):339-47. [PubMed: 8586468]

Prados MD, McDermott M, Chang SM, Wilson CB, Fick J, Culver KW, Van Gilder J, Keles GE, Spence A, Berger M. Treatment of progressive or recurrent glioblastoma multiforme in adults with herpes simplex virus thymidine kinase gene vector-producer cells followed by intravenous ganciclovir administration: a phase I/II multi-institutional trial. J. Neurooncol 2003;65(3):269-78. [PubMed: 14682377]

Puduvalli VK, Sawaya R. Antiangiogenesis -- therapeutic strategies and clinical implications for brain tumors. J. Neurooncol 2000;50(12):189-200. [PubMed: 11245279]

Puri RK. Structure and function of interleukin-4 and its receptor. Cancer Treat. Res 1995;80:143-85. [PubMed: 8821577]

Puri RK, Hoon DS, Leland P, Snoy P, Rand RW, Pastan I, Kreitman RJ. Preclinical development of a recombinant toxin containing circularly permuted interleukin 4 and truncated Pseudomonas exotoxin for therapy of malignant astrocytoma. Cancer Res 1996;56(24):5631-7. [PubMed: 8971168]

Puumalainen AM, Vapalahti M, Agrawal RS, Kossila M, Laukkanen J, Lehtolainen P, Viita H, Paljarvi L, Vanninen R, Yla-Herttuala S. Beta-galactosidase gene transfer to human malignant glioma in vivo using replication-deficient retroviruses and adenoviruses. Hum. Gene Ther 1998;9(12):176974. [PubMed: 9721087]

Qureshi NH, Bankiewicz KS, Louis DN, Hochberg FH, Chiocca EA, Harsh G. R. t. Multicolumn infusion of gene therapy cells into human brain tumors: technical report. Neurosurgery 2000;46(3):663-8. [PubMed: 10719863]discussion 668-9

Rainov NG. A phase III clinical evaluation of herpes simplex virus type 1 thymidine kinase and ganciclovir gene therapy as an adjuvant to surgical resection and radiation in adults with previously untreated glioblastoma multiforme. Hum. Gene Ther 2000;11(17):2389-401. [PubMed: 11096443]

Rainov NG, Dobberstein KU, Sena-Esteves M, Herrlinger U, Kramm CM, Philpot RM, Hilton J, Chiocca EA, Breakefield XO. New prodrug activation gene therapy for cancer using cytochrome P450 4B1 and 2-aminoanthracene/4-ipomeanol. Hum. Gene Ther 1998;9(9):1261-73. [PubMed: 9650611]

Rainov NG, Fels C, Droege JW, Schafer C, Kramm CM, Chou TC. Temozolomide enhances herpes simplex virus thymidine kinase/ganciclovir therapy of malignant glioma. Cancer Gene Ther 2001;8 (9):662-8. [PubMed: 11593335]

Rainov NG, Kramm CM, Banning U, Riemann D, Holzhausen HJ, Heidecke V, Burger KJ, Burkert W, Korholz D. Immune response induced by retrovirus-mediated HSV-tk/GCV pharmacogene therapy in patients with glioblastoma multiforme. Gene Ther 2000;7(21):1853-8. [PubMed: 11110418]

Rainov NG, Ren H. Clinical trials with retrovirus mediated gene therapy--what have we learned? J. Neurooncol 2003;65(3):227-36. [PubMed: 14682373]

Ram Z, Culver KW, Oshiro EM, Viola JJ, DeVroom HL, Otto E, Long Z, Chiang Y, McGarrity GJ, Muul LM, Katz D, Blaese RM, Oldfield EH. Therapy of malignant brain tumors by intratumoral implantation of retroviral vector-producing cells. Nat. Med 1997;3(12):1354-61. [PubMed: 9396605]

Rampling R, Cruickshank G, Papanastassiou V, Nicoll J, Hadley D, Brennan D, Petty R, MacLean A, Harland J, McKie E, Mabbs R, Brown M. Toxicity evaluation of replication-competent herpes simplex virus. (ICP 34.5 null mutant 1716) in patients with recurrent malignant glioma. Gene Ther 2000;7(10):859-66. [PubMed: 10845724]

Rand RW, Kreitman RJ, Patronas N, Varricchio F, Pastan I, Puri RK. Intratumoral administration of recombinant circularly permuted interleukin-4-Pseudomonas exotoxin in patients with high-grade glioma. Clin. Cancer Res 2000;6(6):2157-65. [PubMed: 10873064] 
Recht L, Torres CO, Smith TW, Raso V, Griffin TW. Transferrin receptor in normal and neoplastic brain tissue: implications for brain-tumor immunotherapy. J. Neurosurg 1990;72(6):941-5. [PubMed: 2159987]

Reilly KM, Loisel DA, Bronson RT, McLaughlin ME, Jacks T. Nf1;Trp53 mutant mice develop glioblastoma with evidence of strain-specific effects. Nat. Genet 2000;26(1):109-13. [PubMed: 10973261]

Rich JN, Hans C, Jones B, Iversen ES, McLendon RE, Rasheed BK, Dobra A, Dressman HK, Bigner DD, Nevins JR, West M. Gene expression profiling and genetic markers in glioblastoma survival. Cancer Res 2005;65(10):4051-8. [PubMed: 15899794]

Riley DJ, Nikitin AY, Lee WH. Adenovirus-mediated retinoblastoma gene therapy suppresses spontaneous pituitary melanotroph tumors in Rb+/- mice. Nat. Med 1996;2(12):1316-21. [PubMed: 8946829]

Saito R, Bringas JR, Panner A, Tamas M, Pieper RO, Berger MS, Bankiewicz KS. Convection-enhanced delivery of tumor necrosis factor-related apoptosis-inducing ligand with systemic administration of temozolomide prolongs survival in an intracranial glioblastoma xenograft model. Cancer Res 2004;64(19):6858-62. [PubMed: 15466173]

Saleh M, Jonas NK, Wiegmans A, Stylli SS. The treatment of established intracranial tumors by in situ retroviral IFN-gamma transfer. Gene Ther 2000;7(20):1715-24. [PubMed: 11083492]

Saleh M, Stacker SA, Wilks AF. Inhibition of growth of C6 glioma cells in vivo by expression of antisense vascular endothelial growth factor sequence. Cancer Res 1996;56(2):393-401. [PubMed: 8542597]

Saleh M, Wiegmans A, Malone Q, Stylli SS, Kaye AH. Effect of in situ retroviral interleukin-4 transfer on established intracranial tumors. J. Natl. Cancer Inst 1999;91(5):438-45. [PubMed: 10070943]

Sampson JH, Akabani G, Archer GE, Bigner DD, Berger MS, Friedman AH, Friedman HS, Herndon JE 2nd, Kunwar S, Marcus S, McLendon RE, Paolino A, Penne K, Provenzale J, Quinn J, Reardon DA, Rich J, Stenzel T, Tourt-Uhlig S, Wikstrand C, Wong T, Williams R, Yuan F, Zalutsky MR, Pastan I. Progress report of a Phase I study of the intracerebral microinfusion of a recombinant chimeric protein composed of transforming growth factor. (TGF)-alpha and a mutated form of the Pseudomonas exotoxin termed PE-38. (TP-38) for the treatment of malignant brain tumors. J. Neurooncol 2003;65(1):27-35. [PubMed: 14649883]

Sandmair AM, Loimas S, Puranen P, Immonen A, Kossila M, Puranen M, Hurskainen H, Tyynela K, Turunen M, Vanninen R, Lehtolainen P, Paljarvi L, Johansson R, Vapalahti M, Yla-Herttuala S. Thymidine kinase gene therapy for human malignant glioma, using replication-deficient retroviruses or adenoviruses. Hum Gene Ther 2000;11(16):2197-205. [PubMed: 11084677]

Santambrogio L, Belyanskaya SL, Fischer FR, Cipriani B, Brosnan CF, Ricciardi-Castagnoli P, Stern LJ, Strominger JL, Riese R. Developmental plasticity of CNS microglia. Proc. Natl. Acad. Sci. USA 2001;98(11):6295-300. [PubMed: 11371643]

Sasaki M, Wizigmann-Voos S, Risau W, Plate KH. Retrovirus producer cells encoding antisense VEGF prolong survival of rats with intracranial GS9L gliomas. Int. J. Dev. Neurosci 1999;17(56):579_ 91. [PubMed: 10571419]

Schmidt EE, Ichimura K, Reifenberger G, Collins VP. CDKN2. (p16/MTS1) gene deletion or CDK4 amplification occurs in the majority of glioblastomas. Cancer Res 1994;54(24):6321-4. [PubMed: 7987821]

Schneider T, Gerhards R, Kirches E, Firsching R. Preliminary results of active specific immunization with modified tumor cell vaccine in glioblastoma multiforme. J. Neurooncol 2001;53(1):39-46. [PubMed: 11678429]

Schuler G, Schuler-Thurner B, Steinman RM. The use of dendritic cells in cancer immunotherapy. Curr. Opin. Immunol 2003;15(2):138-47. [PubMed: 12633662]

Sebti SM, Hamilton AD. Design of growth factor antagonists with antiangiogenic and antitumor properties. Oncogene 2000;19(56):6566-73. [PubMed: 11426641]

Serafini B, Columba-Cabezas S, Di Rosa F, Aloisi F. Intracerebral recruitment and maturation of dendritic cells in the onset and progression of experimental autoimmune encephalomyelitis. Am. J. Pathol 2000;157(6):1991-2002. [PubMed: 11106572]

Shah AC, Benos D, Gillespie GY, Markert JM. Oncolytic viruses: clinical applications as vectors for the treatment of malignant gliomas. J. Neurooncol 2003;65(3):203-26. [PubMed: 14682372] 
Shand N, Weber F, Mariani L, Bernstein M, Gianella-Borradori A, Long Z, Sorensen AG, Barbier N. A phase 1-2 clinical trial of gene therapy for recurrent glioblastoma multiforme by tumor transduction with the herpes simplex thymidine kinase gene followed by ganciclovir. GLI328 EuropeanCanadian Study Group. Hum. Gene Ther 1999;10(14):2325-35. [PubMed: 10515452]

Sherr CJ. Cancer cell cycles. Science 1996;274(5293):1672-7. [PubMed: 8939849]

Short MP, Choi BC, Lee JK, Malick A, Breakefield XO, Martuza RL. Gene delivery to glioma cells in rat brain by grafting of a retrovirus packaging cell line. J. Neurosci. Res 1990;27(3):427-39. [PubMed: 2129047]

Simon M, Simon C, Koster G, Hans VH, Schramm J. Conditional expression of the tumor suppressor p16 in a heterotopic glioblastoma model results in loss of pRB expression. J. Neurooncol 2002;60 (1):1-12. [PubMed: 12416540]

Singh RP, Agarwal R. Tumor angiogenesis: a potential target in cancer control by phytochemicals. Curr. Cancer Drug Targets 2003;3(3):205-17. [PubMed: 12769689]

Singh SK, Hawkins C, Clarke ID, Squire JA, Bayani J, Hide T, Henkelman RM, Cusimano MD, Dirks PB. Identification of human brain tumour initiating cells. Nature 2004;432(7015):396-401. [PubMed: 15549107]

Smitt PS, Driesse M, Wolbers J, Kros M, Avezaat C. Treatment of relapsed malignant glioma with an adenoviral vector containing the herpes simplex thymidine kinase gene followed by ganciclovir. Mol. Ther 2003;7(6):851-8. [PubMed: 12788659]

Springer CJ, Antoniw P, Bagshawe KD, Searle F, Bisset GM, Jarman M. Novel prodrugs which are activated to cytotoxic alkylating agents by carboxypeptidase G2. J. Med. Chem 1990;33(2):67781. [PubMed: 2299634]

Springer CJ, Niculescu-Duvaz I. Prodrug-activating systems in suicide gene therapy. J. Clin. Invest 2000;105(9):1161-7. [PubMed: 10791987]

Steiner HH, Bonsanto MM, Beckhove P, Brysch M, Geletneky K, Ahmadi R, Schuele-Freyer R, Kremer P, Ranaie G, Matejic D, Bauer H, Kiessling M, Kunze S, Schirrmacher V, Herold-Mende C. Antitumor vaccination of patients with glioblastoma multiforme: a pilot study to assess feasibility, safety, and clinical benefit. J. Clin. Oncol 2004;22(21):4272-81. [PubMed: 15452186]

Stratmann A, Machein MR, Plate KH. Anti-angiogenic gene therapy of malignant glioma. Acta Neurochir. Suppl.. (Wien) 1997;68:105-10.

Stribbling SM, Friedlos F, Martin J, Davies L, Spooner RA, Marais R, Springer CJ. Regressions of established breast carcinoma xenografts by carboxypeptidase G2 suicide gene therapy and the prodrug CMDA are due to a bystander effect. Hum. Gene Ther 2000;11(2):285-92. [PubMed: 10680842]

Szabo S, Sandor Z. The diagnostic and prognostic value of tumor angiogenesis. Eur. J. Surg. Suppl 1998;582:99-103. [PubMed: 10029373]

Takamiya Y, Short MP, Moolten FL, Fleet C, Mineta T, Breakefield XO, Martuza RL. An experimental model of retrovirus gene therapy for malignant brain tumors. J. Neurosurg 1993;79(1):104-10. [PubMed: 8391069]

Tanaka T, Cao Y, Folkman J, Fine HA. Viral vector-targeted antiangiogenic gene therapy utilizing an angiostatin complementary DNA. Cancer Res 1998;58(15):3362-9. [PubMed: 9699667]

Tanaka T, Manome Y, Wen P, Kufe DW, Fine HA. Viral vector-mediated transduction of a modified platelet factor 4 cDNA inhibits angiogenesis and tumor growth. Nat. Med 1997;3(4):437-42. [PubMed: 9095178]

Thomas CE, Schiedner G, Kochanek S, Castro MG, Lowenstein PR. Peripheral infection with adenovirus causes unexpected long-term brain inflammation in animals injected intracranially with firstgeneration, but not with high-capacity, adenovirus vectors: toward realistic long-term neurological gene therapy for chronic diseases. Proc. Natl. Acad. Sci. USA 2000;97(13):7482-7. [PubMed: 10840055]

Thomas CE, Schiedner G, Kochanek S, Castro MG, Lowenstein PR. Preexisting antiadenoviral immunity is not a barrier to efficient and stable transduction of the brain, mediated by novel high-capacity adenovirus vectors. Hum Gene. Ther 2001;12(7):839-46. [PubMed: 11339900]

Todhunter DA, Hall WA, Rustamzadeh E, Shu Y, Doumbia SO, Vallera DA. A bispecific immunotoxin. (DTAT13) targeting human IL-13 receptor. (IL-13R) and urokinase-type plasminogen activator 
receptor. (uPAR) in a mouse xenograft model. Protein Eng. Des. Sel 2004;17(2):157-64. [PubMed: 15047912]

Tosi D, Valenti R, Cova A, Sovena G, Huber V, Pilla L, Arienti F, Belardelli F, Parmiani G, Rivoltini L. Role of cross-talk between IFN-alpha-induced monocyte-derived dendritic cells and NK cells in priming CD8+ T cell responses against human tumor antigens. J. Immunol 2004;172(9):5363-70. [PubMed: 15100276]

Touraine RL, Vahanian N, Ramsey WJ, Blaese RM. Enhancement of the herpes simplex virus thymidine kinase/ganciclovir bystander effect and its antitumor efficacy in vivo by pharmacologic manipulation of gap junctions. Hum. Gene Ther 1998;9(16):2385-91. [PubMed: 9829537]

Trask TW, Trask RP, Aguilar-Cordova E, Shine HD, Wyde PR, Goodman JC, Hamilton WJ, RojasMartinez A, Chen SH, Woo SL, Grossman RG. Phase I study of adenoviral delivery of the HSVtk gene and ganciclovir administration in patients with current malignant brain tumors. Mol. Ther 2000;1(2):195-203. [PubMed: 10933931]

Trinh QT, Austin EA, Murray DM, Knick VC, Huber BE. Enzyme/prodrug gene therapy: comparison of cytosine deaminase/5-fluorocytosine versus thymidine kinase/ganciclovir enzyme/prodrug systems in a human colorectal carcinoma cell line. Cancer Res 1995;55(21):4808-12. [PubMed: 7585511]

Tsugawa T, Kuwashima N, Sato H, Fellows-Mayle WK, Dusak JE, Okada K, Papworth GD, Watkins SC, Gambotto A, Yoshida J, Pollack IF, Okada H. Sequential delivery of interferon-alpha gene and DCs to intracranial gliomas promotes an effective antitumor response. Gene Ther 2004;11(21): 1551-8. [PubMed: 15343358]

Tunici P, Bissola L, Lualdi E, Pollo B, Cajola L, Broggi G, Sozzi G, Finocchiaro G. Genetic alterations and in vivo tumorigenicity of neurospheres derived from an adult glioblastoma. Mol. Cancer 2004;3 (1):25. [PubMed: 15469606]

Tzeng JJ, Barth RF, Orosz CG, James SM. Phenotype and functional activity of tumor-infiltrating lymphocytes isolated from immunogenic and nonimmunogenic rat brain tumors. Cancer Res 1991;51(9):2373-8. [PubMed: 2015600]

Ueki K, Ono Y, Henson JW, Efird JT, von Deimling A, Louis DN. CDKN2/p16 or RB alterations occur in the majority of glioblastomas and are inversely correlated. Cancer Res 1996;56(1):150-3. [PubMed: 8548755]

Valerie K, Brust D, Farnsworth J, Amir C, Taher MM, Hershey C, Feden J. Improved radiosensitization of rat glioma cells with adenovirus-expressed mutant herpes simplex virus-thymidine kinase in combination with acyclovir. Cancer Gene Ther 2000;7(6):879-84. [PubMed: 10880018]

Vecil GG, Lang FF. Clinical trials of adenoviruses in brain tumors: a review of Ad-p53 and oncolytic adenoviruses. J. Neurooncol 2003;65(3):237-46. [PubMed: 14682374]

Vile RG, Castleden S, Marshall J, Camplejohn R, Upton C, Chong H. Generation of an anti-tumour immune response in a nonimmunogenic tumour: HSVtk killing in vivo stimulates a mononuclear cell infiltrate and a Th1-like profile of intratumoural cytokine expression. Int. J. Cancer 1997;71 (2):267-74. [PubMed: 9139853]

Vincent AJ, Vogels R, Someren GV, Esandi MC, Noteboom JL, Avezaat CJ, Vecht C, Bekkum DW, Valerio D, Bout A, Hoogerbrugge PM. Herpes simplex virus thymidine kinase gene therapy for rat malignant brain tumors. Hum. Gene Ther 1996;7(2):197-205. [PubMed: 8788170]

Voges J, Reszka R, Gossmann A, Dittmar C, Richter R, Garlip G, Kracht L, Coenen HH, Sturm V, Wienhard K, Heiss WD, Jacobs AH. Imaging-guided convection-enhanced delivery and gene therapy of glioblastoma. Ann. Neurol 2003;54(4):479-87. [PubMed: 14520660]

Wang TJ, Huang MS, Hong CY, Tse V, Silverberg GD, Hsiao M. Comparisons of tumor suppressor p53, p21, and p16 gene therapy effects on glioblastoma tumorigenicity in situ Biochem. Biophys. Res. Commun 2001;287(1):173-80.

Wang WJ, Tai CK, Kasahara N, Chen TC. Highly efficient and tumor-restricted gene transfer to malignant gliomas by replication-competent retroviral vectors. Hum. Gene Ther 2003;14(2):117-27. [PubMed: 12614563]

Weaver M, Laske DW. Transferrin receptor ligand-targeted toxin conjugate. (Tf-CRM107) for therapy of malignant gliomas. J. Neurooncol 2003;65(1):3-13. [PubMed: 14649881] 
Weber F, Asher A, Bucholz R, Berger M, Prados M, Chang S, Bruce J, Hall W, Rainov NG, Westphal M, Warnick RE, Rand RW, Floeth F, Rommel F, Pan H, Hingorani VN, Puri RK. Safety, tolerability, and tumor response of IL4-Pseudomonas exotoxin. (NBI-3001) in patients with recurrent malignant glioma. J. Neurooncol 2003;64(12):125-37. [PubMed: 12952293]

Weber FW, Floeth F, Asher A, Bucholz R, Berger M, Prados M, Chang S, Bruce J, Hall W, Rainov NG, Westphal M, Warnick RE, Rand RW, Rommell F, Pan H, Hingorani VN, Puri RK. Local convection enhanced delivery of IL4-Pseudomonas exotoxin. (NBI-3001) for treatment of patients with recurrent malignant glioma. Acta Neurochir. Suppl 2003;88:93-103. [PubMed: 14531567]

Wei MX, Tamiya T, Chase M, Boviatsis EJ, Chang TK, Kowall NW, Hochberg FH, Waxman DJ, Breakefield XO, Chiocca EA. Experimental tumor therapy in mice using the cyclophosphamideactivating cytochrome P450 2B1 gene. Hum. Gene Ther 1994;5(8):969-78. [PubMed: 7948146]

Wei MX, Tamiya T, Rhee RJ, Breakefield XO, Chiocca EA. Diffusible cytotoxic metabolites contribute to the in vitro bystander effect associated with the cyclophosphamide/cytochrome P450 2B1 cancer gene therapy paradigm. Clin. Cancer Res 1995;1(10):1171-7. [PubMed: 9815909]

Weiner NE, Pyles RB, Chalk CL, Balko MG, Miller MA, Dyer CA, Warnick RE, Parysek LM. A syngeneic mouse glioma model for study of glioblastoma therapy. J. Neuropathol. Exp. Neurol 1999;58(1):54-60. [PubMed: 10068314]

Weingart J, Strauss L, Grossman S, Markert J, Tatter S, Fisher JD, Fleming C, Puri RK. Phase I/II study: intra-tumoral infusion of IL13-PE38QQR cytotoxin for recurrent supratentorial malignant glioma. Neurooncology 2002;4:379.

Weissenberger J, Steinbach JP, Malin G, Spada S, Rulicke T, Aguzzi A. Development and malignant progression of astrocytomas in GFAP-v-src transgenic mice. Oncogene 1997;14(17):2005-13. [PubMed: 9160879]

Wiewrodt R, Amin K, Kiefer M, Jovanovic VP, Kapoor V, Force S, Chang M, Lanuti M, Black ME, Kaiser LR, Albelda SM. Adenovirus-mediated gene transfer of enhanced Herpes simplex virus thymidine kinase mutants improves prodrug-mediated tumor cell killing. Cancer Gene Ther 2003;10(5):353-64. [PubMed: 12719705]

Wilson KM, Stambrook PJ, Bi WL, Pavelic ZP, Pavelic L, Gluckman JL. HSV-tk gene therapy in head and neck squamous cell carcinoma. Enhancement by the local and distant bystander effect. Arch Otolaryngol. Head Neck. Surg 1996;122(7):746-9. [PubMed: 8663948]

Witte JS, Palmer LJ, O'Connor RD, Hopkins PJ, Hall JM. Relation between tumour necrosis factor polymorphism TNFalpha-308 and risk of asthma. Eur. J. Hum. Genet 2002;10(1):82-5. [PubMed: 11896460]

Yamanaka R, Zullo SA, Ramsey J, Onodera M, Tanaka R, Blaese M, Xanthopoulos KG. Induction of therapeutic antitumor antiangiogenesis by intratumoral injection of genetically engineered endostatin-producing Semliki Forest virus. Cancer Gene Ther 2001;8(10):796-802. [PubMed: 11687903]

Yang I, Kremen TJ, Giovannone AJ, Paik E, Odesa SK, Prins RM, Liau LM. Modulation of major histocompatibility complex Class I molecules and major histocompatibility complex-bound immunogenic peptides induced by interferon-alpha and interferon-gamma treatment of human glioblastoma multiforme. J. Neurosurg 2004;100(2):310-9. [PubMed: 15086239]

Yoshida J, Mizuno M, Nakahara N, Colosi P. Antitumor effect of an adeno-associated virus vector containing the human interferon-beta gene on experimental intracranial human glioma. Jpn. J. Cancer Res 2002;93(2):223-8. [PubMed: 11856487]

Yoshida J, Mizuno M, Wakabayashi T. Interferon-beta gene therapy for cancer: basic research to clinical application. Cancer Sci 2004;95(11):858-65. [PubMed: 15546502]

Yuan X, Curtin J, Xiong Y, Liu G, Waschsmann-Hogiu S, Farkas DL, Black KL, Yu JS. Isolation of cancer stem cells from adult glioblastoma multiforme. Oncogene 2004;23(58):9392-400. [PubMed: 15558011]

Yukawa H, Takahashi JC, Miyatake SI, Saiki M, Matsuoka N, Akimoto M, Yanamoto H, Nagata I, Kikuchi H, Hashimoto N. Adenoviral gene transfer of basic fibroblast growth factor promotes angiogenesis in rat brain. Gene Ther 2000;7(11):942-9. [PubMed: 10849554] 


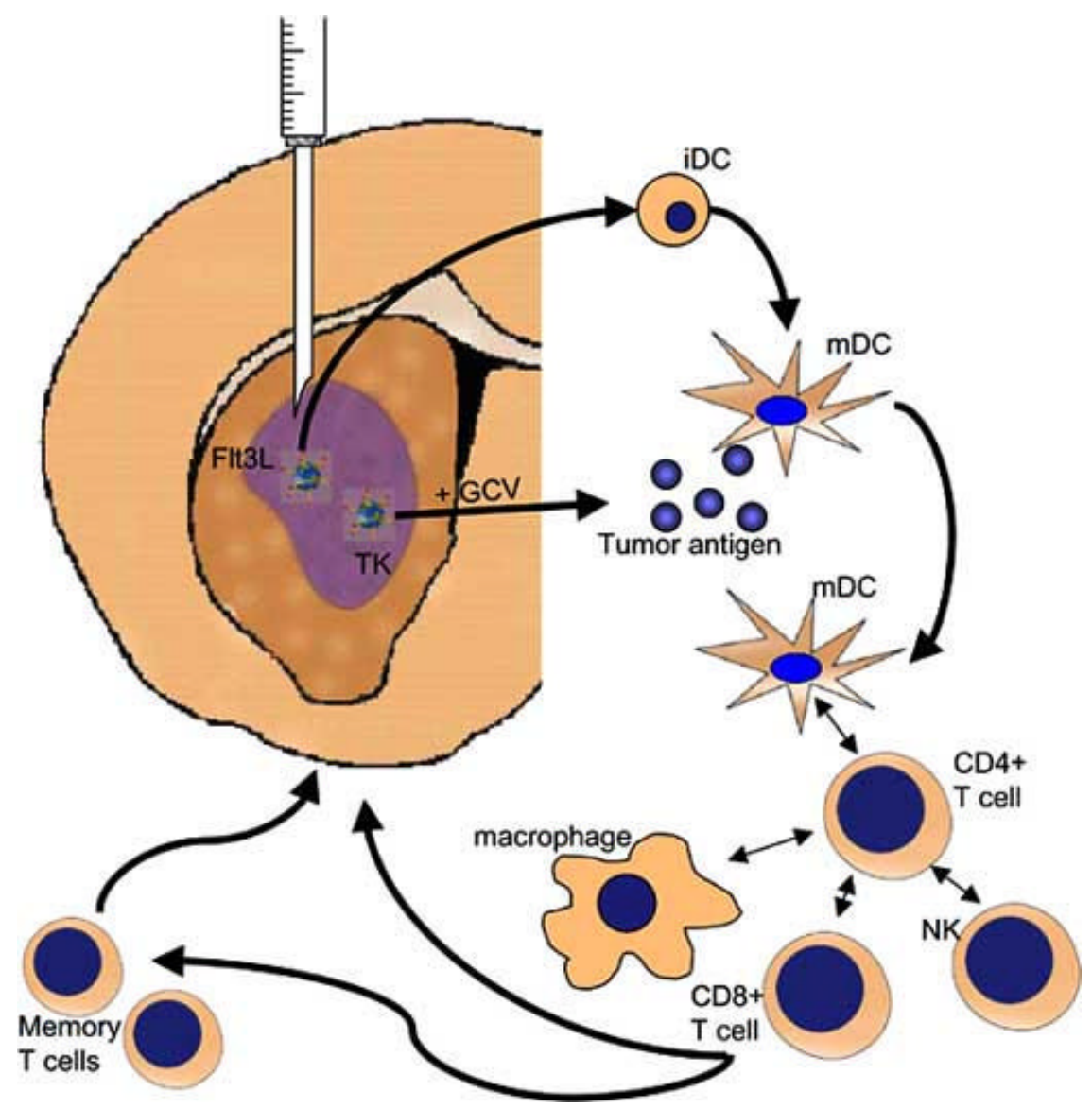

Fig. (1).

Diagram outlining the mechanism by which viral vector administration may result in tumor regression. Adenoviral vectors delivering substances like HSV-1TK and hsFlt3L injected intratumorally cause local cell death (TK) generating tumor antigen and trigger the maturation of local and infiltrating antigen presentating cells (Flt3L). APCs then may activate various adaptive and innate immune system cell types to trigger a fully activated anti-tumor immune response. This immune response also results in memory $\mathrm{T}$ cell generation which protects against future recurrence of disease. 

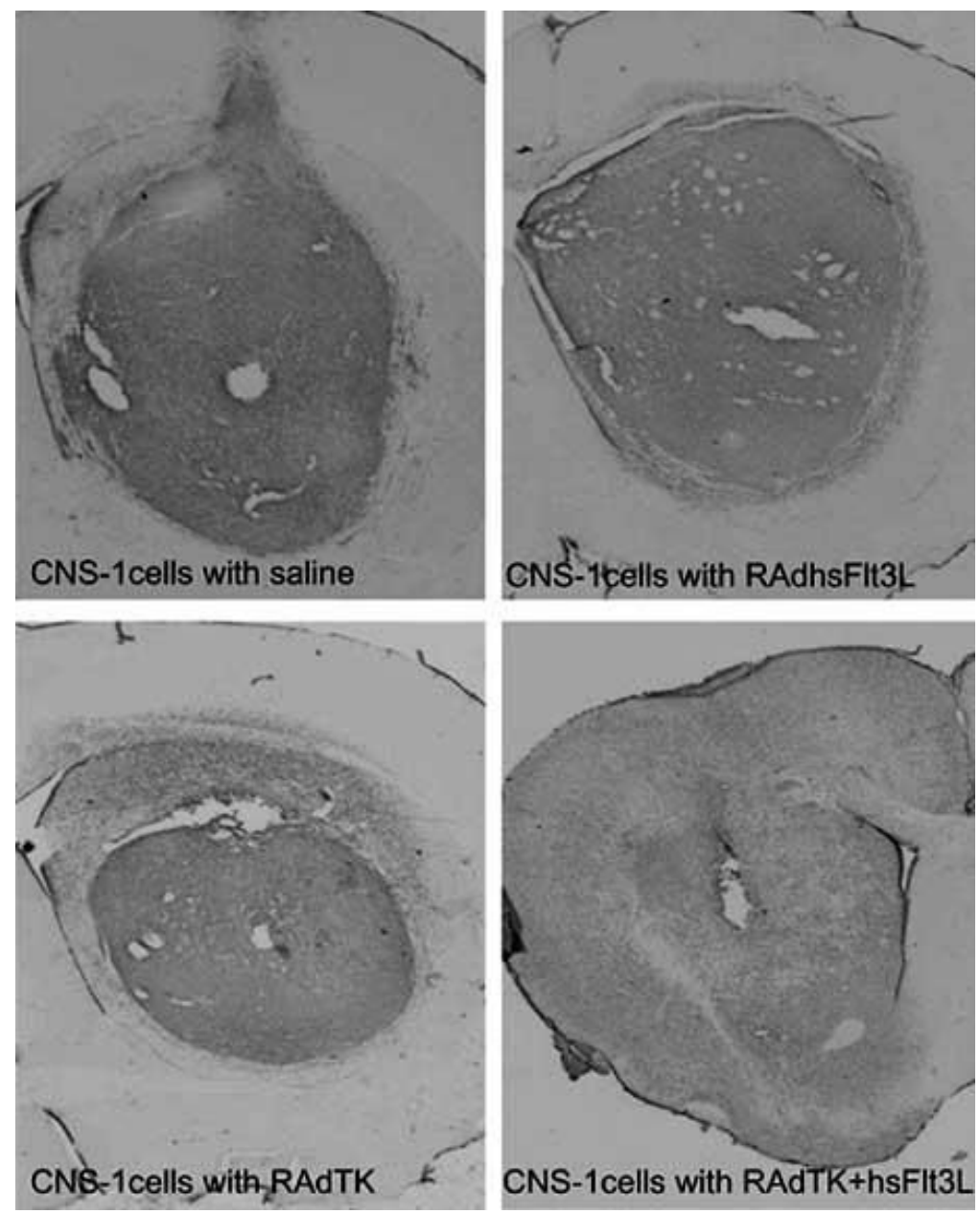

Fig. (2).

CNS-1 cell tumors treated by adenoviral gene therapy. Brains from rats implanted with CNS-1 cell ten days before adenoviral delivery of gene therapy (saline control, RAdhsFlt3L or RAdTK) were harvested five days or twelve (RAdTK+hsFlt3L) days after gene therapy. The combination of immune stimulation and conditional cytoxicity trigger tumor regression [Ali et al., 2005]. Without combined therapy, rats succumb to tumors within 20 days of tumor implantation however with TK + Flt3L treatment, animals survive long term and no tumor remnant is evident 12 days after viral therapy. 


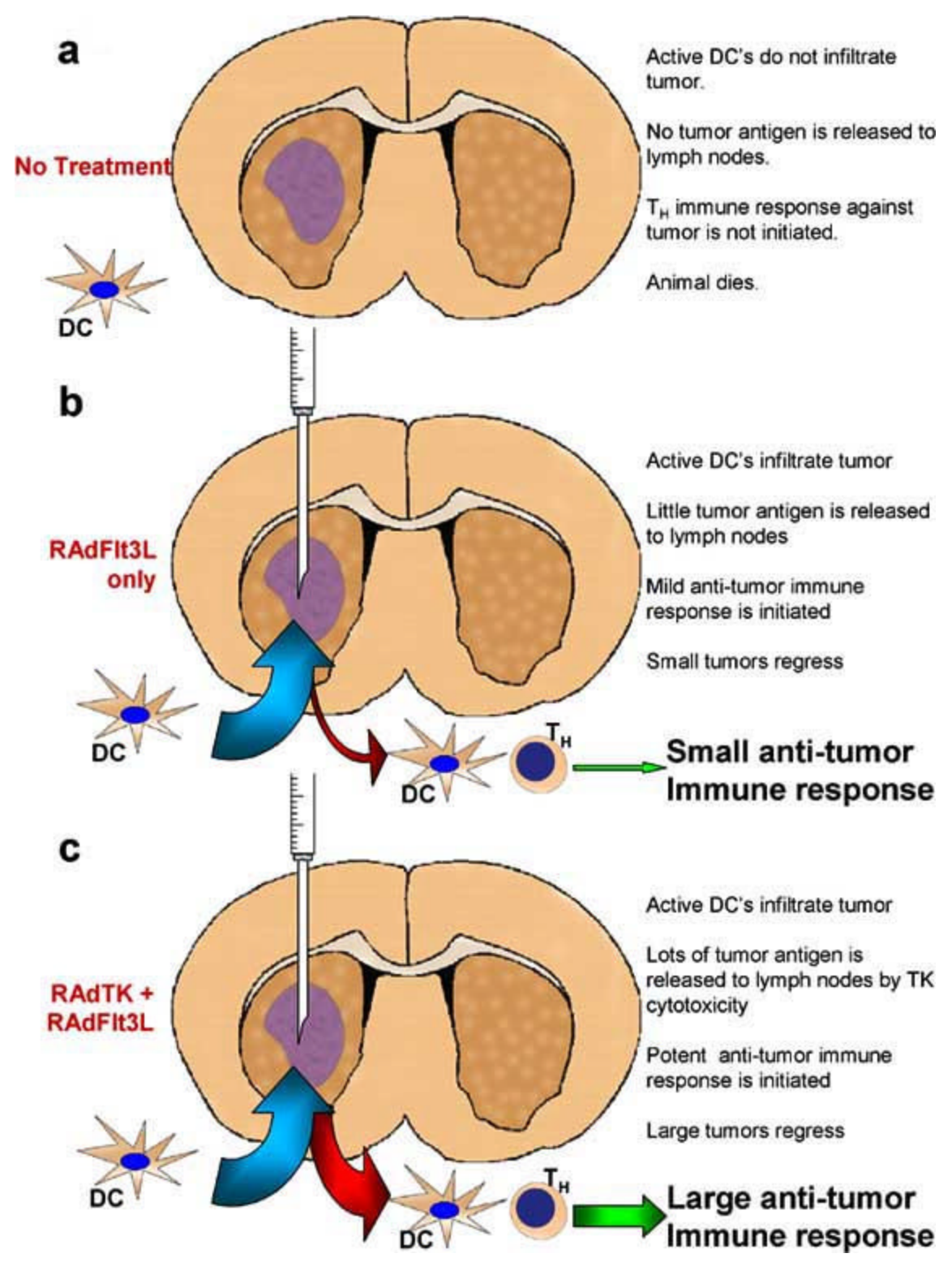

Fig. (3).

Diagram outlining the mechanism through which RAdFIt3L and RAdTK stimulate a powerful anti-tumor response. In the absence of treatment, (a), few dendritic cells (DC's) present in the cerebrospinal fluid (CSF) or peripheral tissues can gain access to the tumor mass growing within the brain parenchyma. This prevents DC's from taking up tumor antigen and migrating to peripheral lymph nodes where it can be presented to $T_{\text {Helper }}\left(T_{H}\right)$ cells. Tumors that are injected with RAdFlt3L alone, (b), allows dendritic cell infiltration into the tumor mass and subsequent maturation. Dendritic cells can proliferate within the tumor, mature, and take up endogenous tumor antigen from necrotic areas within the tumor. These DC's subsequently migrate to peripheral lymph nodes where they present tumor antigen to $\mathrm{T}_{\mathrm{H}}$ cells on MHC II molecules. This results in an immune response against the tumor and can successfully clear small tumors from rodents. Tumors that are injected with both RAdFlt3L and RAdTK, (c), cause the infiltration of DC's within the tumor mass just like with RAdFlt3L alone. However, cytotoxic effects of RAdTK result in necrosis and apoptosis of large areas of the tumor. This creates an inflammatory environment ideal for the uptake of tumor antigen by DC's. These 
DC's migrate to peripheral lymph nodes and display antigen to $\mathrm{T}_{\mathrm{H}}$ lymphocytes, resulting in a potent anti-tumor response sufficient to clear even large tumors from the rodents. 


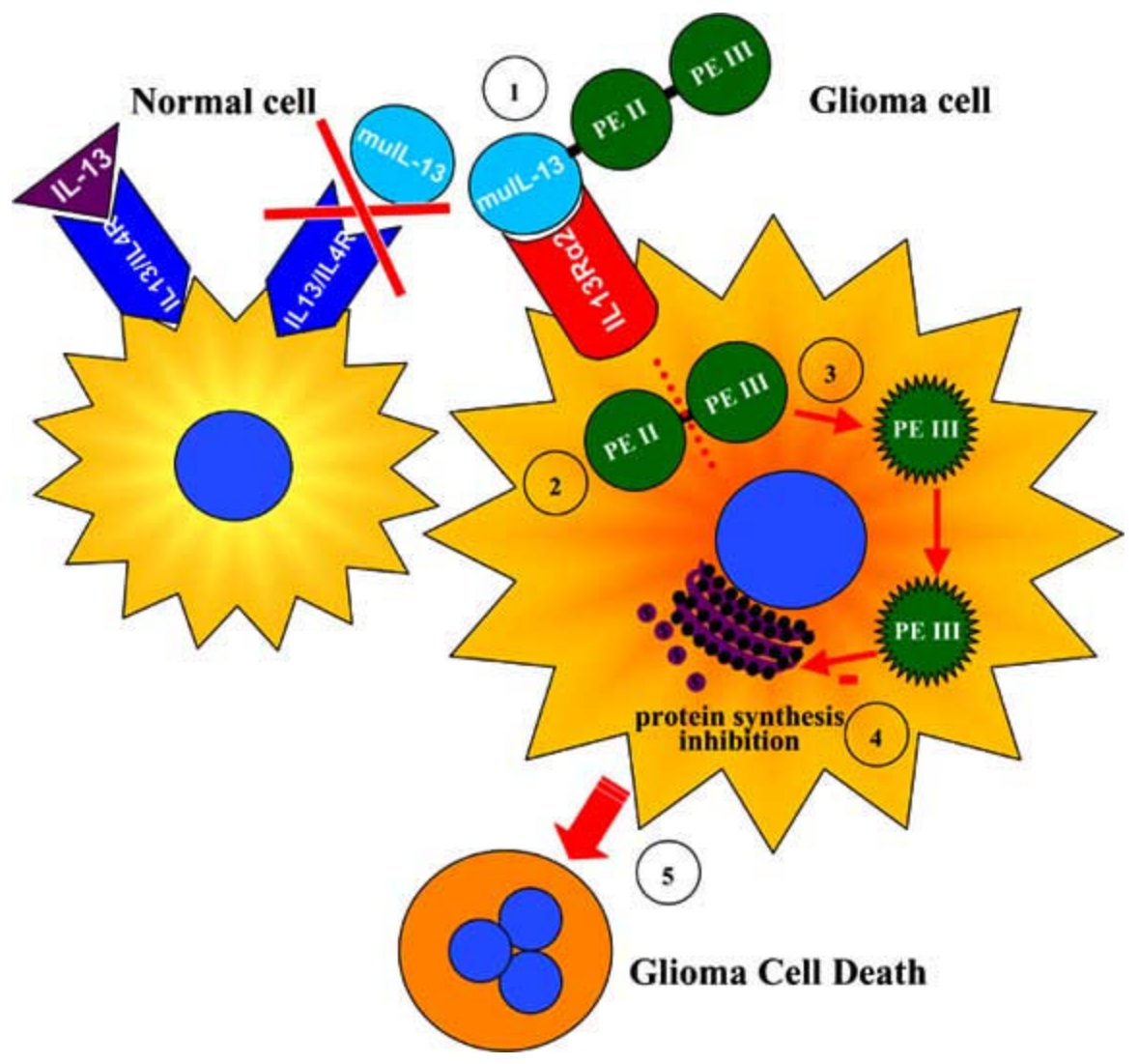

Fig. (4).

Targeted toxins for glioma therapy. The targeting of IL-13 $\alpha 2$ receptor overexpressed in glioma cells has been improved by mutating the human IL- 13 gene to generate a mutated IL-13 (muIL-13). MuIL-13 has shown a higher affinity for the glioma-associated IL-13 2 receptor and negligible binding to the physiological receptor composed of IL-13 receptor and IL-4 receptor (1). The mutant Pseudomonas exotoxin (PE) does not bind to its ubiquitous $\alpha 2$ macroglobulin receptor due to the deletion of domain I and was fused to muIL-13 to promote its internalization into IL-13 $\alpha 2$ R-expressing glioma cells. PE Domain II (PEII) catalyzes the translocation of the toxin into the cytosol (2) and undergoes proteolytic cleavage that activates the exotoxin (3). Domain III (PEIII) directs the processed fragment of the toxin to the endoplasmic reticulum and ADP ribosylates elongation factor 2, inhibiting protein synthesis (4) and leading to glioma cell death (5). 
Table 1

Overview of Clinical Trials for Gene Therapy and Targeted Toxins

\begin{tabular}{|c|c|c|c|}
\hline Treatment tvpe & Molecule & Vector/Deliverv method & Authors of studv \\
\hline Conditional cytotoxcity & $\mathrm{TK}$ & Retrovirus & Izquierdo et al..1997 \\
\hline & & & Ram et al.,1997 \\
\hline & & & Klatzmann et al.,1998 \\
\hline & & & Palu et al..1999 \\
\hline & & & Shand et al..,1999 \\
\hline & & & Harsh et al.,2000 \\
\hline & & & Packer et al.,2000 \\
\hline & & & Rainov et al..2000 \\
\hline & & & Prados et al..2003 \\
\hline & & Adenovirus & Sandmair et al.,2000 \\
\hline & & & Trask et al..2000 \\
\hline & & & Germano et al..2003 \\
\hline & & & Smitt et al..2003 \\
\hline & & & Immonen et al.,2004 \\
\hline & & Nonviral & Jacobs et al.,2001 \\
\hline & & & Voges et al..2003 \\
\hline Targeted toxins & IL-13R-PE & CED & Weingart et al..2002 \\
\hline & & CED & Kuwar et al.,2003 \\
\hline & & CED & Prados et al.,2003 \\
\hline & IL-4R-PE & CED & Rand et al..2000 \\
\hline & & CED & Weber et al..2003 \\
\hline & TGF $\alpha$-PE & CED & Sampson et al.,2003 \\
\hline & Transferrin receptor - DT & CED & Laske et al.,1997 \\
\hline Tumor suppressor & $\mathrm{p} 53$ & Adenovirus & Weaver et al..2003 \\
\hline & & & Lang et al..2003 \\
\hline Oncolytic viruses & ONYX-015 & Adenovirus & Shah et al.,2003 \\
\hline & & & Chiocca et al.,2004 \\
\hline & G207 & Herpes Simples Virus & Markert et al..2000 \\
\hline & HSV1716 & Herpes Simplex Virus & Rampling et al..2000 \\
\hline & & & Papanastassiou et al.,2002 \\
\hline & & & Harrow et al.,2004 \\
\hline & & Newcastle disease virus & Schneider et al..2001 \\
\hline & & & Steiner et al..2004 \\
\hline
\end{tabular}

